\title{
Antalya MP's in Turkish Multi Party Period
}

\author{
D. Ali ARSLAN*, Gülten ARSLAN**, Zehra SÖZER***, Sadettin BAŞTÜRK****, Kadir \\ ULUSOY***** \\ *Mersin Üniversitesi, **Bağımsız, ***Dicle Üniversitesi, ****Mersin Üniversitesi, ***** \\ Mersin Üniversitesi \\ E-mail: cimderaslan@hotmail.com* / gultenb.arslan@hotmail.com**
}

Copyright (C) 2015 D. Ali ARSLAN, Gülten ARSLAN, Zehra SÖZER, Sadettin BAŞTÜRK, Kadir ULUSOY. This is an open access article distributed under the Eurasian Academy of Sciences License, which permits unrestricted use, distribution, and reproduction in any medium, provided the original work is properly cited.

\begin{abstract}
In this study, the deputies who play a vital role in the power structure of society are chosen as the research subjects. The political elites have a different and important place among the elite groups. The deputies form one of the most basic elements of the political elite. They play the strategic roles within the decision-making process and the structure of society. Antalya deputies, along with the lawmakers from the other provinces, form the most important part of the Turkish political elite. This study was designed to find general characteristics of Antalya MP's in Multi Party Period (Since 1946 up to Date). On the final stage the place of Antalya MP's in Turkish political elites will be examined. Social background peculiarities (gender, age, education, occupation, family size) were used to achieve the objectives. Documentary and historical research techniques were applied in the paper. An original data set was produced for analysis from the official publications and records and publications of the Turkish Grand National Assembly which is the main legislative organ in Turkey. The data set was analysed by using SPSS (Statistical Package for the Social Sciences). Findings clearly show that some social groups have been over representing, the others have been under represented amongst Antalya MP's.
\end{abstract}

Keywords: Antalya, Antalya MP's, Antalya MP's in Multi Party Period, Political Structure of Antalya, Elite, Power, Political Elite, Turkish Political Elites

\section{Çok Partili Dönem Türk Siyasal Hayatında Antalya Milletvekilleri}

\section{ÖZET}

$\mathrm{Bu}$ çalışmada, toplumun iktidar yapısı içinde hayati bir rol oynayan milletvekilleri araştırma konusu olarak seçilmiştir. İktidar yapısı içindeki konumları, sahip oldukları siyasal ve toplumsal güç, karar verme sürecinde oynadıkları belirleyici rol, kontrol ettikleri materyal ve maddi olmayan kaynaklar bakımından toplumsal hiyerarşinin en üst katmanlarını oluşturan elitler, toplumda ayrıcalıklı bir konuma sahiptirler. Karar alma sürecinin ve toplumun yapısının şekillendirilmesinde de stratejik roller üstlenirler. Siyasi elitlerin ise elit grupları içinde ayrı bir yeri ve önemi vardır. Milletvekilleri, siyasi elitlerin en temel unsurlarından birini oluştururlar. Antalya milletvekilleri de, öteki illerin milletvekilleri ile birlikte, Türk siyasi elitlerinin en önemli bileşenlerini oluştururlar. Bu realiteden hareketle araştırmada, 
Antalya milletvekillerinin sosyolojik profillerinin incelenmesi hedeflendi. $\mathrm{Bu}$ amaç doğrultusunda, Türk siyasi elitlerinin oluşturduğu araştırma evreninden, 1946-2014 y1lları arasında, Türkiye Büyük Millet Meclisi'nde görev yapmış ve yapmakta olan Antalya parlamenterleri örneklem kümesi olarak seçildi. "Konumsal Analiz Tekniğii" temel alınarak, temel veri kaynağı olarak, TBMM'nin kurumsal kayıtları ve yayınları, özellikle de meclis albümleri kullanıldı. Bu kaynaklardan elde edilen verilerden, bilgisayar ortamında, çok partili dönemde Antalya milletvekilliği yapmış siyasi elitlerin toplumsal özgeçmişleri ile ilgili bir data (veri) seti hazırlandı. Bu veri setleri SPSS kullanılarak analiz edildi. Hazırlanan veri seti yaş, cinsiyet, eğitim, mesleksel özgeçmiş, aile yapısı gibi temel sosyal ve demografik faktörler temelinde analiz edildi. Bulgular, sosyolojik profilleri bağlamında Antalya milletvekillerinin eşitlikçi olmayan bir görünüm sergilediğini ortaya koymaktadır. Bazı toplum kesimleri, Antalya milletvekilleri arasında daha fazla temsil edilirken, öteki bazı kesimler toplumsal yapı içindeki oranlarına göre daha az temsil edilmekte, bazı kesimler ise hiç temsil edilme imkânı bulamamaktadır.

Anahtar Kelimeler: Antalya, Antalya Milletvekilleri, Çok Partili Dönemde Antalya Milletvekilleri, Antalya'nın Siyasi Yapısı, Elit, İktidar, Siyasi Elit, Türk Siyasi Elitleri

\section{GíRIŞ}

Bu çalışmada, en önemli sahil kentlerimizden biri olan Antalya'nın iktidar yapısı içinde belirleyici roller üstlenmiş Antalya milletvekilleri araştırıldı. Araştırmada, elit sosyolojisinin (Arslan, 2007; Scott, 1993) kuramsal ve metodolojik birikiminden yararlanıld1.

Bilindiği gibi, Cumhuriyet dönemi Türk siyasal hayatı en genel hatlarıyla, tek partili dönem ve çok partili dönem olmak üzere, iki ana döneme ayrılarak incelenir. Kimi araştırmacılar Çok Partili Dönemi 1950'den, bazıları ise 1946 yılından başlatırlar. Her ikisinin de belirli bir doğruluk payı vardır. Zira ülkemizin modern siyasi tarihinde, gerçek anlamda bir demokratik çok partili dönem, 1950 yılında başlamıştır. Bununla birlikte, 1945 ve 1946'lı yılların, toplumsal ve siyasal hayatımızdaki önemini de küçümsememek gerekir. Çünkü ülkemizin siyaset sahnesinde, CHP dışında başka siyasi partilerin varlık göstermeye başlaması bu y1llarda gerçekleşmiştir.

Bunun da ötesinde, 23 yıllık bir zaman dilimi boyunca, siyasi hayatta tek parti olmanın ayrıcalığını elinde bulunduran CHP'nin, öteki tek parti rejimlerinde (Örneğin İtalya ve Rusya'da) pek rastlanılmayacak bir şekilde (Duverger, 1995; 1964) iktidarı, başka siyasi kadrolarla paylaşma gönüllülüğü ve olgunluğu göstermesi gözden ırak tutulmamalıdır. İktidarı hem de, kendi içinden çıkmış kadrolarla paylaşmış olması daha ayrı bir anlam ifade eder.

Özetle 1946-1950 yılları ülkemizde, çok partili hayatın başlangıcında bir geçiş dönemi olarak görülse de, en azından yukarıda vurgulanan gerekçelerle, bu geçiş döneminin önemi yadsınamaz. Zira bu geçiş, son derece yumuşak, kansız ve gözyaşı olmaksızın gerçekleştirilmiştir. 1946 seçimleri her ne kadar, gerçek demokratik seçim ilkeleri ile çelişen 
bazı özellikler arz etse de, sonuçta siyasal iktidar da, ilerleyen süreçte Türkiye'nin siyasi ve toplumsal kaderinde belirleyici roller üstlenecek bir siyasi geleneğin, Türk siyasi hayatında tohumları atılmıştır. Başka bir anlatımla, siyasal hayatımızda Demokrat Parti’li yılların başlangıcıdır bu geçiş dönemi. Demokrat Parti'nin öncüsü olan merkez sağ siyaset geleneği, takip eden süreçte, onlarca yıl boyunca Türkiye'nin siyasi ve toplumsal kaderinde belirleyici roller üstlenmiş ve üstlenmeye de devam etmektedir.

$\mathrm{Bu}$ araştırmada da, sosyoloji ve siyaset biliminde sıklıkla ön plana çıkan bu geleneğe riayet edildi. Bu bağlamda araştırma zaman boyutunda sınırlandırıldı. Çalışmada, zaman boyutu bakımından Çok partili dönem seçildi ve tabi ki bu dönemin başlangıcı olarak da 1946 yılı baz alındı. Bu anlayış doğrultusunda, 1946 yılından günümüze, yalnızca Antalya ili ve kentinin siyasi ve toplumsal hayatında değil, Türkiye'nin de politik ve sosyal hayatında önemli görevler icra eden Antalya milletvekilleri, sosyolojik açıdan araştırıldı. Bu gerçekleştirilirken elit sosyolojisinin teori (Etzioni, 1997; 1993; Scott, 1990; 1991; 1993; 1995) ve yöntemleri (Gilbert, 1994; Moyser \& Wagstaffe, 1987) kullanıldı. Bu yüzden, araştırmanın bulgularına geçmeden önce, söz konusu teorik ve metodolojik temele kısa bir göz atmak faydalı olacaktır.

\section{KAVRAMSAL VE KURAMSAL TEMEL}

Araştırmanın temel kavramları iktidar, elit ve siyasi elit kavramlarıdır. Latince kökenli bir sözcük olan "Elit” kavramı, Fransızca'dan dilimize geçmiştir (Arslan, 2012: 588-9). Amerika ve İngiltere olmak üzere batılı ülkelerde ise 1930'lu yıllarda akademik hayatta yaygın olarak kullanılmaya başlanmıştır (Mosca, 1939). Bu kavramın kökenini, Fransız sosyologu Henri de Saint Simon'a kadar indirmek mümkündür (Arslan, 2013-a; Arslan, 2013-b: 45-47). Bununla birlikte kavram akademik ününü, İtalyan sosyolog Pareto'ya borçludur. Pareto (1968) elit'i, belirli hiyerarşik yapılanmalar içinde en üst konumu elinde bulunduranlar veya kendi faaliyet alanının en iyileri, en etkilileri olarak tanımlar (Arslan, 1995: 12).

Kavramının, çağdaş elit sosyolojisi literatüründeki tanımı ise, Pareto'nun klasik tanımından biraz daha farklılık gösterir. Teorik açıdan elit, kurumsal iktidara sahip, toplumsal kaynakları kontrol edebilecek konumda bulunan, karar verme sürecini doğrudan ya da dolaylı olarak ciddi bir şekilde etkileyebilen (Dahl, 1961), karşıtlarına rağmen istek ve amaçlarını gerçekleştirebilen bireyler şeklinde tanımlanabilir (Arslan, 2005-a; Arslan, 2004-h; Arslan, 2012).

Metodolojik boyuttan incelendiğinde ise elitler, önemli ya da stratejik toplumsal kurumların en üst ya da karar verme sürecine en yakın konumlarını işgal eden bireyler olarak tanımlanabilir (Arslan, 2013-a; Frey, 1969; Turhan, 1991; Landau, 1980). Toplumun en önemli ve en stratejik kurumları arasında ise başta siyaset kurumu olmak üzere (Arslan, 2004c; Arslan, 2004-d), ekonomi (Arslan, 2003-e), ordu (Arslan, 2004-j), yarg1, eğitim ve medya (Arslan, 2004-1) gibi kurumlar sayllabilir. 
Öte yandan ikinci ana kavram ise siyasi elitlerdir (Arslan, 2011-a). Konu teorik açıdan ele alındığında ise siyasi elitlerin, siyaset kurumu içinde, toplum ve bireyler açısından hayati önem arz eden konumları işgal eden; toplum hayatı açsından belirleyici kararları alınmasında söz sahibi durumdaki bireylerden oluştuğu açıkça gözler önüne serilir. Bu kavramın sınırları içine, başta Cumhurbaşkanı ve meclis başkanı olmak üzere, başbakan ve bakanlar, siyasi parti liderleri ve milletvekilleri girer. Bu bireyler sahip oldukları gücü ve kontrol ettikleri sosyal, ekonomik, siyasal kaynakları kullanarak toplumsal hayata yön ve şekil verirler (Arslan, 2011-b; Arslan, 2011-c).

Antalya milletvekilleri Türk siyasi elitlerinin en önemli bileşenlerindendir. Bu çalışmada, pratik sebeplerden dolayı siyasi elit kavramının sınırları biraz daha daraltıldı ve milletvekilleri ile sınırlandırıldı. Türk siyasi elitleri arasından da Antalya milletvekilleri araştırma konusu olarak belirlendi.

Araştırmanın üçüncü önemli kavramı ise iktidar terimidir. Arslan (2007: 7-8)'in de belirttiği gibi iktidar, güç ya da erk, sosyal ilişkiler dizgesi içinde anlam kazanan bir toplumsal ilişkiler sistemidir. Weberci anlayıştan (Weber, 1968) hareketle iktidar, toplumsal kararların şekillenmesinde etkili ve yetkili olma, karşıtlarının direncine rağmen amaçlarını gerçekleştirebilme yetisi olarak da tanımlanabilir.

Kurmasal boyutta ise, daha önce de vurgulandığ 1 gibi, araştırmada kuramsal temel olarak elit teorisi kullanıldı. Elit Teorisi (Etzioni, 1997; 1993; Scott, 1990; 1991; 1993; 1995) çok öz olarak toplumu, "azlar" ve "çoklar" olarak iki kategoriye ayırır. Toplumda iktidar sahibi az'lardır ve çoklar'ı yönetirler. Yöneten toplumsal erk, az'ların tekelindedir ve hayati toplumsal kararlar bu azınlık grup tarafından verilir. İktidarı kontrol eden azlar "elit"; toplumsal hayattaki rolleri ve izleyeceği rotalar genellikle azlarca belirlenen çoklar ise "halk" olarak adlandırılır (Arslan, 2012-a; Arslan, 2003-a; 2003-b).

Elit teorisi dört alt kola ayrılır: Çoğulcu elit teorisi, elitist ya da seçkinci elit teorisi, demokratik elit teorisi ve demo elit perspektif. Bu çalışmada ağırlıklı olarak elitist ya da seçkinci elit teorisi olarak adlandırılan elit teorisi kullanılacaktır. Kısaca seçkinci elit teorisinin kökenleri Pareto, Michels ve Mosca'ya kadar eskidir. Önemli elit araştırmacılarından Moyser (1987: 5), ilk seçkinci düşünür olarak Michels’i kabul ederken, Bachrach (1967: 10) ilk elitist teorisyen olarak Mosca’ya önem atfeder. Hewitt'göre ise, öncü Amerikalı elitist teorisyenler C. Wright Mills, F. Hunter (1959) ve W. Domhoff (1970); önemli İngiliz elitistler ise Aaronowitch $(1961,1959)$ ve Miliband'dır.

Mosca'ya göre toplum, genellikle bir azınlık grubu tarafından yönetilir. Bu dominant grup, doğal ayıklanma veya siyasi seçim yoluyla çoğunluk içinden çıkar ve etkin bir şekilde çoğunluğu yönetir (Meisel, 1962: 371). Bu etkin grup, toplumsal yaşamda karşı konulması zor bir güce ve göz ardı edilemeyen bir etkiye sahiptirler. 
Plüralist teorinin karşıtı fikirleri savunan seçkinci elit teorisine göre iktidar, toplumun iktidar yapısı içindeki sayıca az fakat en güçlü insanların oluşturduğu elit grubunda yoğunlaşmış ve merkezileşmiştir (Presthus, 1964: 10). Bu elit grubu, öteki gruplar üzerinde baskın ve etkindir. $\mathrm{Bu}$ baskın grup, ötekilerin bilmediklerini bilecek, ötekilerin yapamadıklarını yapabilecek konumda ve güçtedir (Thoenes, 1966: 42).

\section{ARAŞTIRMANIN YÖNTEMI}

Çalışmanın önceki bölümlerinde de vurgulandığı gibi araştırmada, Antalya milletvekillerinin sosyolojik açıdan incelenmesi hedeflendi. Belirlenen amaca ulaşabilme için elit sosyolojisinin (Hertz \& Imber, 1995; Arslan, 2007; Moyser \& Wagstaffe, 1987) yöntem ve teknikleri (Gilbert, 1994) kullanıldı. Araştırma evreni olarak Türk siyasi elitleri seçildi. Araştırma evreni, zaman boyutunda sınırlandırılarak, 1946-2014 yılları çalışma evreni olarak tanımlandı. Bu araştırma evreninden örneklem kümesi olarak, 1946-2014 yılları arasında, Türkiye Büyük Millet Meclisi çatısı altında, Antalya milletvekili olarak görev yapmış/yapmakta olan milletvekilleri seçildi. Milletvekillerini tanımlarken metodolojik olarak "Konumsal Analiz Tekniği”" kullanıldı. Temel veri kaynağı olarak TBMM'nin kurumsal kayıtları ve yayınları, özellikle de meclis albümleri (TBMM, 2003; TBMM, 2000; TВMM, 1997; ТВMM, 1994; ТВMM, 1992) kullanıldı. 17 parlamento dönemini kapsayan bu verilerden hareketle çok partili dönemde (Arslan, 2005-b) Antalya milletvekilliği yapmış siyasi elitlerin toplumsal özgeçmişleri ile ilgili bir veri seti oluşturuldu. Bu veri seti, sosyal biliciler arasında yaygın olarak kullanılan bir veri düzenleme ve analizi programı olan SPSS (Healey, 1993; Fielding, 1995; Gilbert, 1997; Altunışık, 2004) ortamında analiz edildi.

Araştırma, betimleyici türden bir sosyolojik araştırma şeklinde tasarlandı. Bu bağlamda araştırmada, bir bakıma Antalya milletvekillerinin sosyolojik portrelerinin ortaya konması amaçlandı. Ele alından dönemde görev yapmış Antalya milletvekilleri, sosyolojik olarak incelenirken yaş, cinsiyet, eğitim, mesleksel özgeçmiş, aile yapısı gibi sosyal ve demografik faktörler kullanıldı. Araştırmanın ikinci boyutunda ise ulaşılan bulgular ile çok partili dönem (Arslan 2003-d) Türk siyasi elitleri (Çağlar \& Arslan 2000) konusunda daha önce yapılmış çalışmaların bulguları birbirleri ilintilendirilmeye çalışıldı.

Araştırmada özellikle, şu soruların ve bunlarla bağlantılı alt soruların cevapları araştırıldı (Arslan, 2013-a):

- $\quad$ Antalya'nın siyasi yapısı içinde milletvekili seçilebilmek için yaş faktörü belirleyici bir etkiye sahip midir?

- Genç (Orta-genç) yaş grubu milletvekili adaylarının, Antalya'da milletvekili seçilme olasılı̆̆ 1 , ileri yaş grubu bireylere oranla daha mı yüksektir?

- $\quad$ Bazı meslek grupları, Antalya'da siyasi elit dolaşım sürecinde daha belirleyici etkiye sahip midir?

- $\quad$ Milletvekili adaylarının üst düzey bürokrat-yönetici olması, Antalya'da milletvekili seçilmesinde pozitif yönde bir etki yapar mı?

- Meslek olarak hukukçu milletvekili adaylarının Antalya'dan milletvekili seçilebilme olasılığı öteki meslek gruplarına oranla daha mı yüksektir? 
- $\quad$ Meslek olarak tüccar ve sanayicilik kökenli olmak, Antalya’dan milletvekili seçilme sürecinde pozitif yönde bir etki yapar mı?

- Milletvekili adaylarının cinsiyeti, Antalya'dan milletvekili seçimi sürecinde belirleyici bir etkiye sahip midir?

- Milletvekili adaylarının erkek olması, Antalya'da milletvekili seçimi sürecinde pozitif yönde bir etki yapar mı?

- $\quad$ Yabancı dil bilmek, Antalya'da milletvekili seçimi sürecinde pozitif yönde bir etki yapar mi?

- $\quad$ Eğitim durumu Antalya'da milletvekili seçimi sürecinde belirleyici bir etkiye sahip midir?

- Aldığı eğitimin miktarı arttıkça, milletvekili adayının Antalya'dan milletvekili seçilme olasılı̆̆ da artmakta mıdır?

- $\quad$ Üniversite mezunu olmak, milletvekili adayının Antalya'dan milletvekili seçilmesinde pozitif yönde belirleyici rol oynar mi?

- $\quad$ Alınan eğitimin türü milletvekili adayının Antalya'dan milletvekili seçilmesinde pozitif yönde etki yapar mi?

- $\quad$ Metropol kentlerdeki köklü üniversitelerden alınan diplomalar, milletvekili adayının Antalya'dan milletvekili seçilmesinde pozitif yönde etki yapar mı?

- Milletvekili adayının medeni durumu, Antalya'dan milletvekili seçilmesinde olumlu yönde etki yapar mı?

- $\quad$ Evli olmak, bireylerin milletvekili seçilmesini olumlu yönde etkiler mi?

\section{GEÇMIŞTEN GELECEĞE ANTALYA MILLETVEKİLLERI}

En basit tanımı ile toplumda elitler ve halk arasında gerçekleşen hareketlilik, elitlerin dolaşımı olarak adlandırılır (Arslan, 2007: 8). Elit dolaşımı, elitlerin deveranı olarak da adlandırılır ve bu süreçte birçok faktör önemli rol oynar. Bireylerin, elit konumlarına ulaşmasında doğuştan sahip olunan aristokratik faktörler rol oynayabileceği gibi, çalışmak ve bireysel çabalarla elde edilen demokratik faktörler de etkili olabilir. Bireylerin elit pozisyonlarına ulaşmasında rol oynayan toplumsal faktörler arasında, başta yaş ve cinsiyet olmak üzere eğitim durumu, alınan eğitimin türü, eğitim görülen okul, ailesel öz geçmiş, aile yapısı, medeni durum, yabancı dil bilgisi ... gibi birçok faktör sayılabilir. Bu bağlamda Antalya milletvekilleri yaş faktörü bağlamında nasıl bir görünüm sergilemektedirler sorusunun cevabı arandığında şöyle bir tablo ile karşılaşılır:

\subsection{YAŞ ÖZELLİKLERİ BAKIMINDAN ANTALYA MILLETVEKİLLERİ}

Siyasi elitlerin dolaşım sürecinde belirleyici rol oynayan faktörler arasında ilk akla gelen yaş faktörüdür. Türk siyasi elitlerinin (Arslan, Baştürk vd., 2014: 6) genel profilinin yanı sıra, Antalya milletvekillerinin siyasi elit konumuna ulaşmasında da önemli rol oynadığ düşünülmektedir. İlk dört tablodaki ve Grafik 1'deki bulgular, bu savı destekler doğrultudadır.

1946'dan 2014'e, 17 dönem boyunca parlamentoda Antalya'y1 temsil etmiş toplam 153 milletvekilinin sosyal profilleri incelendiğinde, milletvekillerinin yaş ortalamasının 48,55 
olduğu gerçeği ortaya çıkar. Bu bulgu, yaş bakımından Antalya milletvekillerinin, orta yaşa yaklaşmış genç milletvekili özelliği gösterdiği konusunda önemli ipucu verir. Tablo 1'de de görüldüğü gibi Antalya milletvekillerinin yaş ortalaması, Türkiye ortalamasına biraz üzerindedir. 2000'li yılların başından itibaren ise Antalya milletvekillerinin yaşlarında dikkat çekici bir artış gözlemlenir (Tablo 3).

Tablo-1

Antalya Milletvekillerinin ve Türk Siyasi Elitlerinin Yaş Ortalaması

\begin{tabular}{||l|c|c||}
\hline \multirow{2}{*}{ Ortalama Yaş } & \multicolumn{2}{|c||}{ 1946'dan Günümüze Siyasi Elitler } \\
\cline { 2 - 3 } & Türkiye Geneli & Antalya \\
\hline \hline
\end{tabular}

Kaynak: Arslan'ın 2014 yılında gerçekleştirdiği araştırmanın verileri temel alınarak hazırlanmıştır.

Tablo-2

Antalya Milletvekillerinin Yaş Özellikleri

\begin{tabular}{|l|l|c|}
\hline \multicolumn{2}{||}{} & $\begin{array}{c}\text { Antalya Milletvekillerinin } \\
\text { Yaş Özellikleri }\end{array}$ \\
\hline $\mathrm{N}$ & Geçerli & 153 \\
\cline { 2 - 3 } & Eksik & 0 \\
\hline Ortalama Yaş & 48.55 \\
\hline Medyan & 47 \\
\hline Mod & 43 \\
\hline Minimum Yaş & 31 \\
\hline & \\
\hline Maksimum Yaş & 73 \\
\hline
\end{tabular}

Kaynak: Arslan'ın 2014 yılında gerçekleştirdiği araştırmanın verileri temel alınarak hazırlanmiştır.

Antalya milletvekillerinin yaşlarına ilişkin daha ayrıntılı istatistik bilgiler ise Tablo 2'de görülebilir. İncelenen süreçte Antalya milletvekilliği yapmış parlamenterlerin en genci 31 yaşında iken, en yaşlısı 73 yaşındadır. 153 milletvekilinin yaşlarının medyanı 47; modu ise 43'dür. Başka bir anlatımla, Antalya milletvekillerinin yarısının yaşı 48,5'in altında, yarısının ki ise üstündedir. Yine yaş bakımdan en çok sayıyı 43 yaşındaki milletvekilleri oluşturmaktadır.

Antalya milletvekillerinin yaşları, dönemler bazında incelendiğinde de oldukça önemli bulgular ile karşılaşılır. Tablo 3 ve Grafik 1'de sergilenen bulgular, bu konuda daha ayrıntılı analizlere imkân sunar. Ortalama yaş bakımından en genç milletvekili grubu Antalya'yı, 12. Dönem parlamentosunda temsil etmiştir. Daha açık bir anlatımla, Türkiye Büyük Millet Meclisi çatısı alından Antalya'yı temsil eden, Antalya siyasi tarihinin en genç milletvekilleri grubu, 1961 y1lı seçimlerinde iş başına gelmiştir. Bu dönem Antalya milletvekillerinin ortalama yaşı 40 ’tır. 


\section{Tablo-3}

1946'dan Günümüze Antalya Milletvekillerinin Yaş Ortalamaları

\begin{tabular}{||l|c|c|c||}
\hline \multirow{2}{*}{} & \multicolumn{3}{|c|}{ 1946'dan Günümüze Antalya Milletvekilleri } \\
\cline { 2 - 4 } & Ortalama Yaş & Milletvekili Sayısı & Standart Sapma \\
\hline 8. Dönem (1946) & 53,8571 & 7 & 5,61036 \\
\hline 10. Dönem (1950) & 47,0000 & 7 & 12,27464 \\
\hline 11. Dönem (1957) & 46,5000 & 8 & 10,50170 \\
\hline 12. Dönem (1961) & 42,6667 & 9 & 9,65660 \\
\hline 13. Dönem (1965) & 40,0000 & 7 & 7,14143 \\
\hline 14. Dönem (1969) & 42,8571 & 7 & 4,33699 \\
\hline 15. Dönem (1973) & 45,1429 & 7 & 2,34013 \\
\hline 16. Dönem (1977) & 46,2857 & 7 & 6,82433 \\
\hline 17. Dönem (1983) & 46,7143 & 7 & 7,95224 \\
\hline 18. Dönem (1987) & 55,1429 & 7 & 10,93052 \\
\hline 19. Dönem (1991) & 45,8750 & 8 & 5,64263 \\
\hline 20. Dönem (1995) & 46,1111 & 9 & 5,53273 \\
\hline 21. Dönem (1999) & 47,1000 & 10 & 7,15619 \\
\hline 22. Dönem (2002) & 46,7500 & 12 & 8,67730 \\
\hline 23. Dönem (2007) & 52,7692 & 13 & 9,63634 \\
\hline 24. Dönem (2011) & 54,7692 & 13 & 9,49696 \\
\hline \multicolumn{1}{|c|}{ Ortalama-Toplam } & 54,7333 & 15 & 11,90718 \\
\hline \hline
\end{tabular}

Kaynak: Arslan’ın 2014 yılında gerçekleştirdiği araştırmanın verileri temel alınarak hazırlanmıştır.

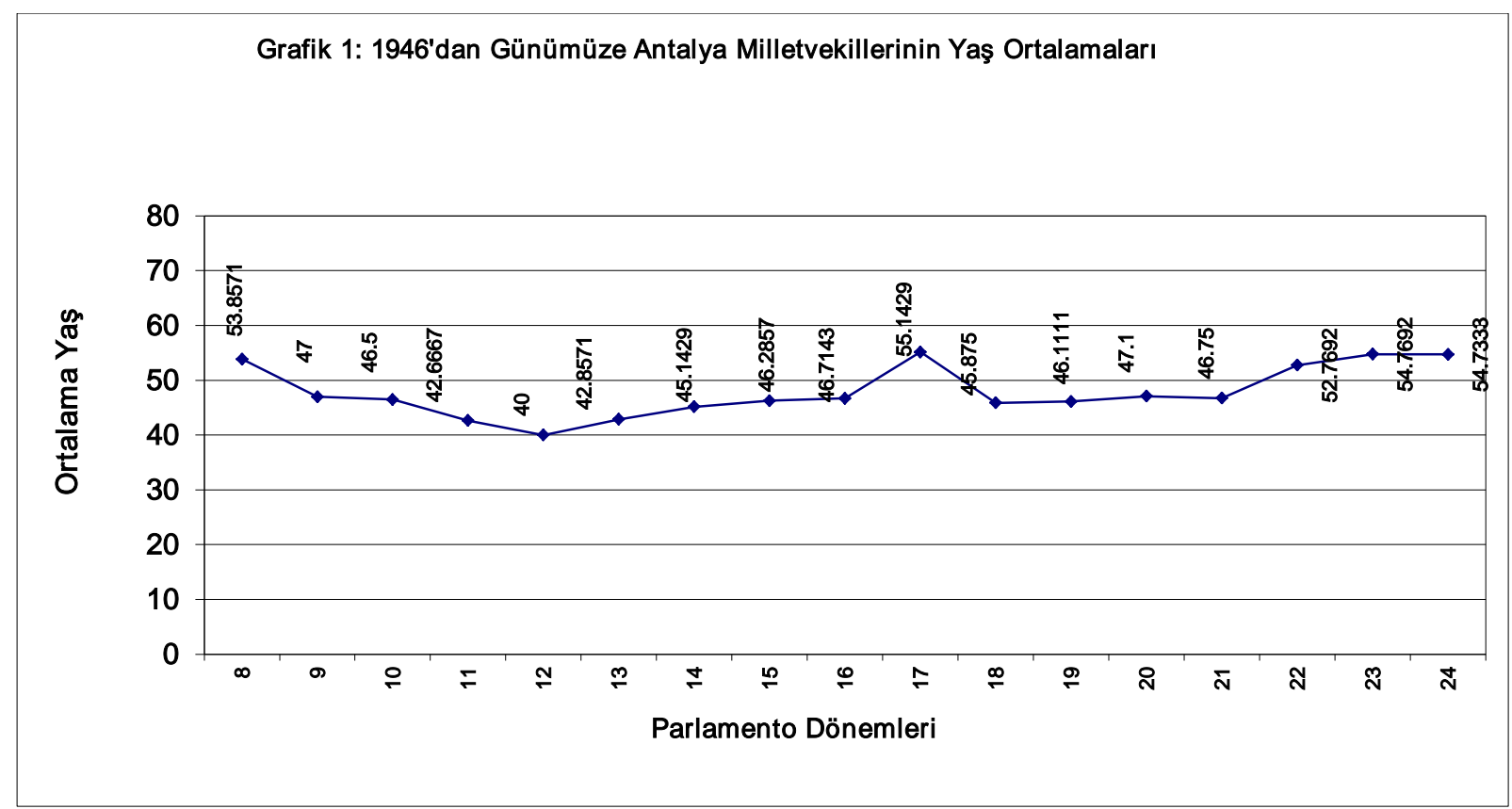


Takip eden süreçte, Antalya milletvekillerinin yaş ortalamasında küçük dalgalanmalar yaşanmış olsa da, son iki dönem parlamentosunda yaş ortalamasında kayda değer bir artış gözlemlenir. Antalya 23. ve 24. dönem parlamentolarında, en yaşlı milletvekili grubu tarafından temsil edilmiştir. 2007 ve 2011 dönemlerinde Antalya milletvekillerinin yaş ortalamas1 54,7'dir.

\section{Tablo-4}

Antalya Milletvekillerinin Yaş Gruplarına Göre Dağglımı

\begin{tabular}{||l|l|c|c|c|}
\hline \multicolumn{2}{|c|}{} & Sayı & Yüzde (\%) & Toplamalı Yüzde \\
\hline \multirow{4}{*}{ Yaş Grupları } & $30-34$ & 6 & 3,9 & 3,9 \\
\cline { 2 - 5 } & $35-44$ & 54 & 35,3 & 39,2 \\
\cline { 2 - 5 } & $45-54$ & 52 & 34,0 & 73,2 \\
\cline { 2 - 5 } & $55-64$ & 33 & 21,6 & 94,8 \\
\cline { 2 - 5 } & 65 ve + & 8 & 5,2 & 100,0 \\
\hline
\end{tabular}

Kaynak: Arslan’ın 2014 yılında gerçekleştirdiği araştırmanın verileri temel alınarak hazırlanmıştır.

Antalya milletvekillerinin profilleri, yaş gruplarına dağılım temelinde incelendiğinde ise daha çarpıcı bulgular ile karşılaşılır. Ele alınan bütün dönemler ortalaması incelendiğinde, genç ve genç-orta yaş grubunun Antalya milletvekilleri arasında dominant konumda oldukları gerçeği ile karşılaşılır. Tablo 4'te de görüldüğü gibi, 55 yaş altı milletvekillerinin Antalya milletvekilleri içindeki yeri yüzde 73 civarındadır. En büyük yaş grubu ise yüzde 35 'lik temsil gücü ile 35-44 yaş grubudur. Öte yandan 65 yaş ve üzerindeki bireylerin Antalya'da milletvekili seçilme şansı ise bir hayli düşüktür. Tüm dönemler bazında, toplam 53 milletvekili içinde, 65 yaş üstünde yalnızca 8 aday Antalya'dan milletvekili seçilme şansı bulabilmiştir.

\subsection{ANTALYA MILLETVEKILLERININ MESLEKSEL ÖZGEÇMIŞLERİ:}

Siyasal iktidarı şekillendiren elit dolaşım sürecinde rol oynayan önemli toplumsal faktörlerden biri de mesleksel özgeçmiştir. Toplumsal yapı içinde bazı meslekler gruplarının üyeleri, diğerlerine kıyasla daha etkili ve belirleyici konumdadırlar. Bu mesleklerin mensubu bireyler, mesleklerinin kendilerine sunduğu sosyal, psikolojik ve ekonomik ayrıcalıklar ve güç sayesinde, elit dolaşım sürecinde ön plana çıkmaktadırlar.

$\mathrm{Bu}$ saptamalar 1şı̆̆ında, mesleksel konumun elit dolaşım süreci üzerindeki etkisini ortaya koyabilmek için, 1946'dan günümüze Antalya'yı TBMM çatışı altında temsil etmiş 153 milletvekilinin, mesleksel özgeçmişleri de araştırıldı. Bulgular, Antalya milletvekilleri arasında, özellikle üniversite hocalarında oluşan eğitimcilerin ön plana çıktığını göstermektedir (Tablo 5 ve Grafik 2). Bu meslek grubunu mensuplarını hukukçular (avukat, hâkim ve savcilar), sivil bürokrasi ve özel sektörde yöneticilik deneyimi olan parlamenterler, tıp doktorları, mühendis ve mimarlar izler. 


\section{Tablo-5}

Antalya Milletvekillerinin ve Türk Siyasi Elitlerinin Mesleksel Özgeçmişleri

\begin{tabular}{|l|c|c||}
\hline \multirow{2}{*}{\multicolumn{1}{c|}{ MESLEKLER }} & \multicolumn{2}{c||}{ Antalya Milletvekilleri } \\
\cline { 2 - 3 } & Sayı & \% \\
\hline Sivil Bürokrat \& Yönetici & 19 & 12,4 \\
\hline Hukukçu (avukat-hâkim-savcı) & 20 & 13,1 \\
\hline Mühendis \& Mimar & 19 & 12,4 \\
\hline Tıpçı & 19 & 12,4 \\
\hline Müteahhit & 1 & 0,7 \\
\hline Eŭitim & 30 & 19,6 \\
\hline Asker-Polis & 4 & 2,6 \\
\hline Tüccar \& Sanayici & 11 & 7,2 \\
\hline Ziraat-Orman Mühendisi & 9 & 5,9 \\
\hline Din Adamı & 2 & 1,3 \\
\hline Gazeteci-Yazar & 3 & 2,0 \\
\hline Çiftçi & 10 & 6,5 \\
\hline Ötekiler & 6 & 3,9 \\
\hline Toplam & 153 & $\mathbf{1 0 0}$ \\
\hline \hline
\end{tabular}

Kaynak: Arslan'ın 2014 yılında gerçekleştirdiği araştırmanın verileri temel alınarak hazırlanmıştır.

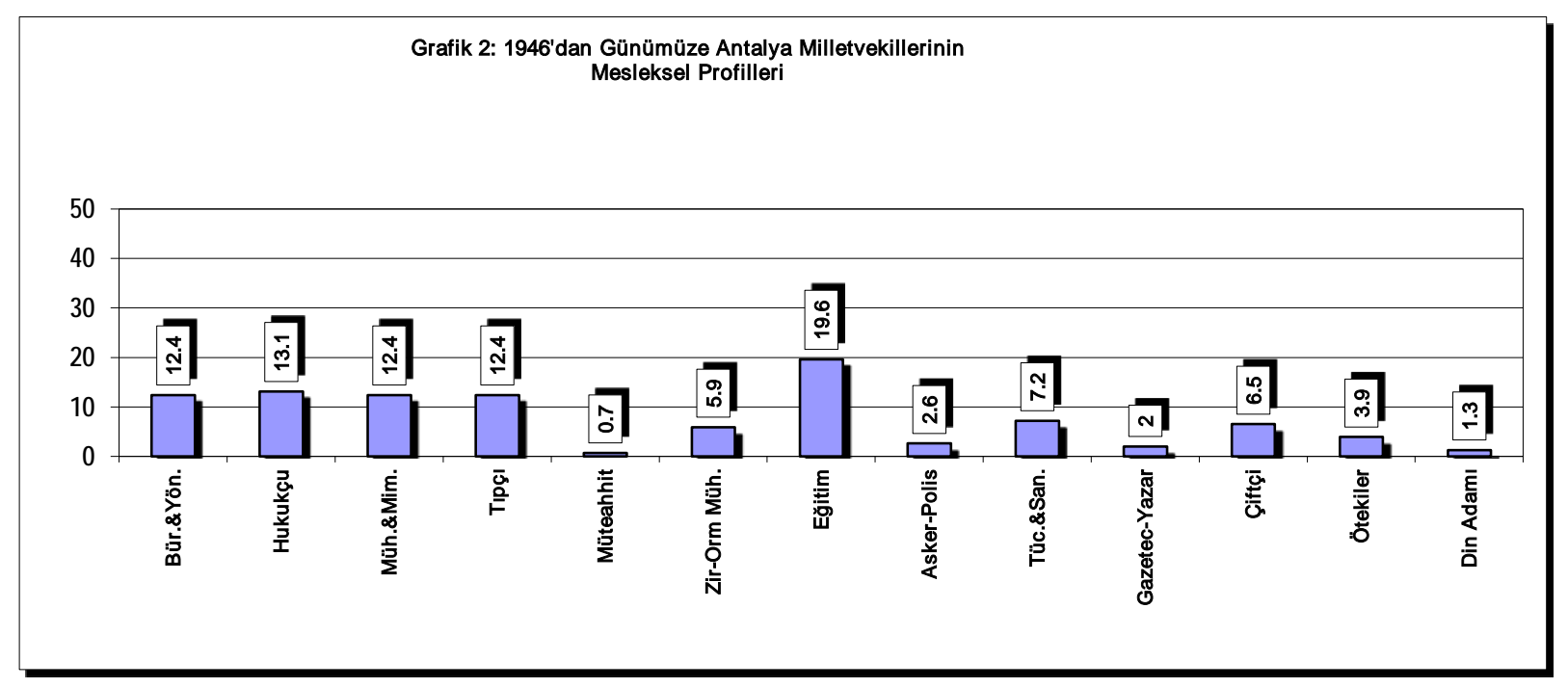

Öte yandan Antalya özelindeki bulgular, Türkiye geneline ilişkin bulgular (Arslan, 2005-a) ile kıyaslandığında, Antalya'nın Türkiye'nin siyasi yapısı içindeki yerine ilişkin önemli ipuçları ile karşılaşılır. Türk siyasi yaşamında en önemli ağırlığı üç meslek grubunu hukukçular, sivil bürokrat ve yöneticiler ile tüccar ve sanayiciler oluştururlar. Bu üç meslek grubunun Türk siyasi elitleri arasında toplam temsil edilme oranı yüzde 58'i aşmaktadır (Arslan, 2005-a; Arslan, 2013-a). Türkiye genelinde en güçlü meslek grubu hukukçular oluştururken, Antalya'da ilk sırayı üniversite hocaları alır. Akademisyenlerin Antalya milletvekilleri arasında temsil edilme oranı, Türkiye genelinden yaklaşık 3 kat daha fazladır. Bu durum 
Antalya'nın toplumsal ve kültürel hayatında, bilime ve bilim insanlarına atfedilen değer ve önemin bir göstergesi olarak da kabul edilebilir.

Antalya milletvekillerini mesleksel profiline ilişkin öteki bulgular da, Antalya'da iktidarın yapısını Türkiye genelinden oldukça farklı olduğu gerçeğini ortaya koyar. Örneğin hukukçu milletvekilleri ile sivil bürokrasi ve özel sektör yöneticiliği kökenli milletvekillerinin Antalya milletvekilleri arasındaki yeri, Türkiye genelinin son derece altındadır. Buna karşın, doktorluk ve mühendislik kökenli milletvekillerinin oranı Türkiye ortalamasından kat be kat fazladır (2012-b; Arslan 2013).

\subsection{ANTALYA MILLETVEKILLERİNIN EĞITTIM DÜZEYLERİ VE YABANCI DİL BİLGISİ}

Eğitim olgusu, günümüz toplumlarında önemi her geçen gün daha da artan bir toplumsal olgudur. Toplumsal statü ve saygınlık kazanmada en etkili faktörlerin biri olan eğitimin, nicel olduğu kadar nitel boyutları da önemlidir.

Tablo-6

Antalya Milletvekillerinin ve Türk Siyasi Elitlerinin Eğitim Düzeyleri

\begin{tabular}{|l|c|c|}
\hline \multirow{2}{*}{\multicolumn{1}{|c|}{ Eğitim Düzeyi }} & Türkiye Geneli (\%) & Antalya Milletvekilleri (\%) \\
\cline { 2 - 3 } & & 88,9 \\
\hline Üniversite & 80.1 & 7,8 \\
\hline Lise & 8.3 & 3,3 \\
\hline Ortaokul & 7.3 & 0 \\
\hline İlkokul & 4.3 & 100 \\
\hline Toplam & 100 & virk Siyasi Elitleri \\
\hline
\end{tabular}

Kaynak: Arslan'ın 2014 yılında gerçekleştirdiği araştırmanın verileri temel alınarak hazırlanmıştır.

Eğitim, toplumsal hayatin birçok yönünde olduğu kadar siyasal hayatta ve özellikle de elitlerin dolaşımı sürecinde (Pareto, 1968) oldukça belirleyici rol oynar. Bu saptama, Türk toplumu açısından da geçerlidir. Çok Partili Dönem Türk siyasi elitlerinin beşte dördünden fazlasının üniversite mezunudur (Arslan, 1995). Oysa Türkiye genel nüfusu içinde üniversite mezunlarının oranının yüzde 10’u bile bulmadığı gerçeği(Arslan, 2005-a: 18) dikkate alındığında, genelde Türk siyasi elitlerinin ve özelde de Antalya milletvekillerinin sergilediği elitist görünümün boyutları daha bir netlik kazanır (Tablo 6).

Antalya'da siyasal iktidarın şekillenmesinde, eğitim olgusunun ve özellikle de eğitimin niceliksel boyutlarının belirleyici etkisini gözlemlemek mümkündür. Milletvekillerinin, eğitim düzeyi bakımından incelendiğinde, Antalya milletvekillerinin eğitim durumunun, Türkiye ortalamasından oldukça farklı bir görünüm sergilediği açık bir şekilde gözler önüne serilir. Tablo 6'da da görüldüğü gibi Antalya milletvekillerinin yüzde 90'a yakını üniversite 
mezunudur. Antalya milletvekilleri arasında üniversite mezunlarının oranı Türkiye geneli ortalamasından oldukça üzerindedir. Bu bulgular, bir önceki bölümde Antalyalıların bilime ve eğitime büyük değer atfettiği yönündeki bulguları da destekler doğrultudadır. Antalya milletvekilleri arasında, hiçbir ilkokul mezunu hiç kimse bulunmamaktadır. Ortaokul ve lise mezunlarının temsil edilme oranı da, Türk siyasi elitleri ortalamasının oldukça altındadır. Bütün bu bulgulardan hareketle, eğitim düzeyi bakımından Antalya milletvekillerinin seçkinci bir karakter sergilediği kolaylıkça söylenebilir. Bu elitist görünüm, Türk siyasi elitlerinden çok daha yüksek düzeydedir.

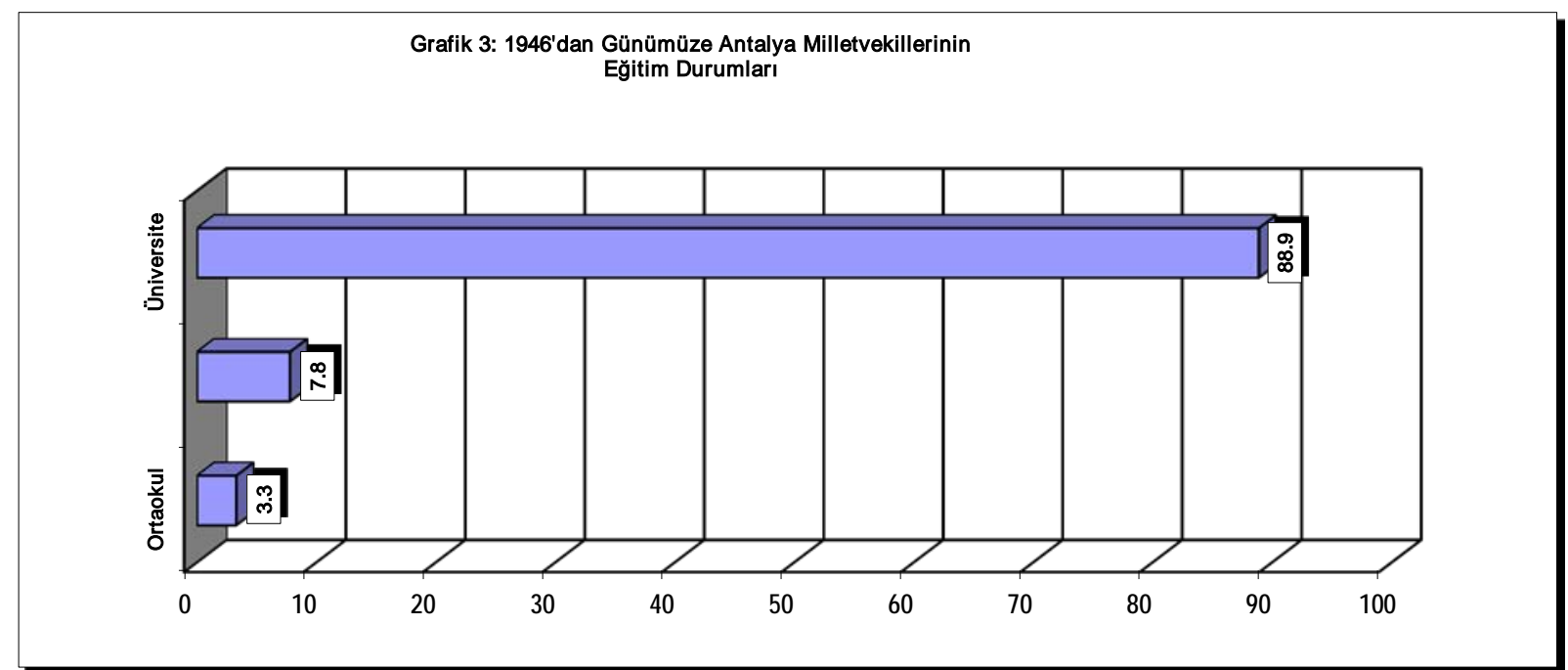

Kaynak: Arslan'ın 2014 yılında gerçekleştirdiği araştırmanın verileri temel alınarak hazırlanmıştır.

Öte yandan bulgular arasında daha detaylı incelendiğinde, Antalya milletvekillerinin profillerine ilişkin daha özgün bulgular ile karşılaşılır. Grafik 3 ve 4'te de görüldüğü gibi, ilköğretim mezunu (ilkokul ve ortaokul bir arada) milletvekillerinin oranı yalnızca yüzde 3 civarındadır. Buna karşın en az lise eğitimi görmüş milletvekillerinin oranı ise yüzde 97’ye yaklaşır. Üniversite mezunu milletvekillerinin oranı ise yüzde 89 civarında olup, Türkiye ortalamasından yüzde 10 daha fazladır. 


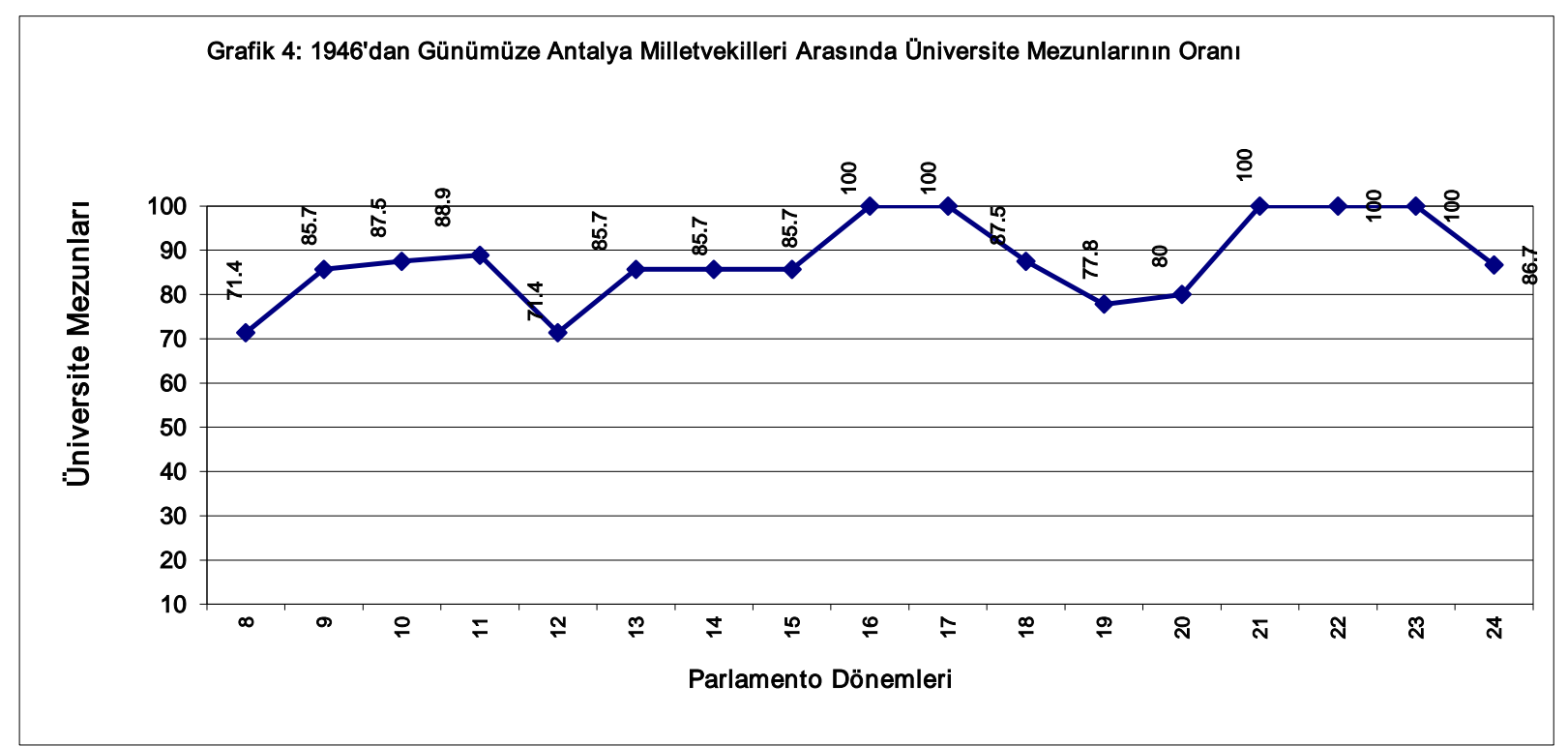

Kaynak: Arslan'ın 2014 yılında gerçekleştirdiği araştırmanın verileri temel alınarak hazırlanmıştır.

Üniversite mezunu milletvekillerinin dönemsel dağılımı incelendiğinde de oldukça dikkat çekici bulgular ile karşılaşılır. 5 dönem Antalya milletvekillerinin tamamı üniversite mezunudur: Bu dönemler16, 17, 21, 22 ve 23. Dönemlerdir. Antalya milletvekilleri arasında üniversite mezunu milletvekillerinin en düşük olduğu dönem ise 8 . ve 12. dönem parlamentolarıdır (Grafik 4 ve Tablo 7).

Antalya milletvekillerinin eğitim düzeyleri dönemler bazında incelendiğinde daha ayrıntılı bilgilere ulaşılır: Dört dönem dışında, Antalya milletvekillerinin tamamı lise ya da üniversite mezunudur (Tablo 7). Daha net bir anlatımla incelenen on yedi parlamento döneminin on üç döneminde, Antalya milletvekilleri arasında ilkokul ya da ortaokul mezunu hiçbir milletvekili bulunmamaktadır. Ele alınan süreçte görev almış toplam 153 milletvekilinden, yalnızca 5 tanesi ortaokul ve 12 tanesi lise mezunudur. 


\section{Tablo-7}

1946’dan Günümüze Antalya Milletvekillerinin Eğitim Düzeyleri

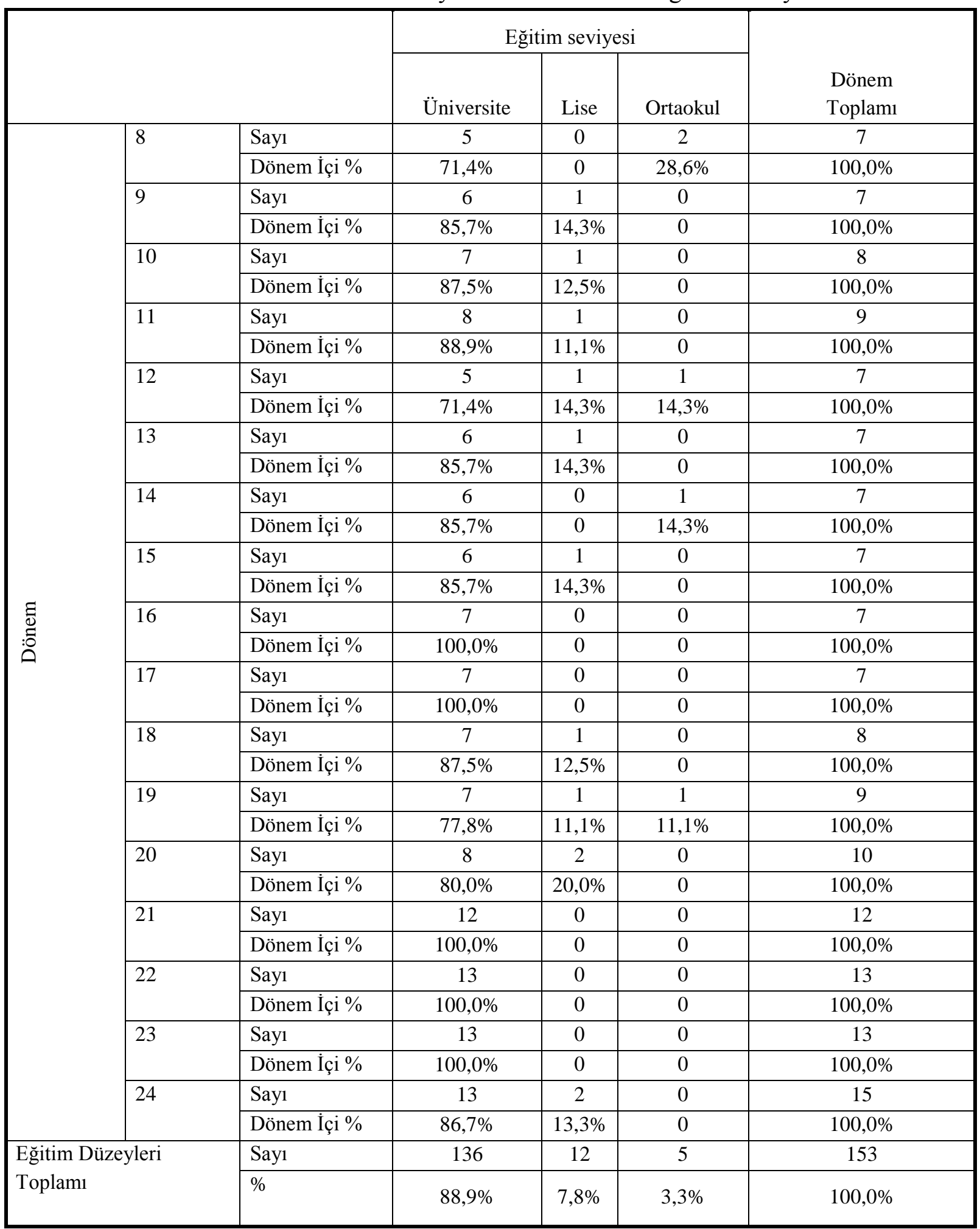

Kaynak: Arslan'ın 2014 yılında gerçekleştirdiği araştırmanın verileri temel alınarak hazırlanmıştır. 
Tablo-8

Antalya Milletvekillerinin Yabanc1 Dil Bilgisi

\begin{tabular}{|l|c||}
\hline & 1946'dan Günümüze Antalya Milletvekilleri \\
& (\%) \\
\hline Yabancı Dil Bilmiyor & 23,5 \\
\hline Bir Yabancı Dil Bilen & 49,0 \\
\hline İki Yabancı Dil Bilen & 17,6 \\
\hline Üç Yabancı Dil Bilen & 7,2 \\
\hline Dört ve Yukarısı & 2,6 \\
\hline \multicolumn{1}{|c||}{ Toplam } & 100 \\
\hline \hline
\end{tabular}

Kaynak: Arslan'ın 2014 yılında gerçekleştirdiği araştırmanın verileri temel alınarak hazırlanmıştır.

Eğitim olgusu ile ilişkili olarak incelenen bir diğer faktör ise yabancı dil bilgisidir. Günümüzde, etkisi toplumsal hayatın her boyutunda ağır bir şekilde hissedilen küreselleşme olgusunun da doğal bir sonucu olarak yabancı dil bilmenin önemi her geçen gün daha da artmaktadır. "Bir lisan, bir insan" özdeyişinde de dile getirildiği gibi, yabancı dil bilmenin bireylerin niteliksel gelişimi ve mesleksel kariyerleri açısından ne kadar büyük bir önem taşıdığı su götürmez bir gerçektir. Yabancı dil bilgisi, elit dolaşım sürecinde de bireyleri avantajlı ve ayrıcalıklı hale getirmektedir. Bilinen her bir yabancı dil bireylere dışa açılmada, öteki topluma ve kültürlerden olan bireyler ile iletişim kurabilmede, toplumsal ve siyasal yaşama etkin bir şekilde katılabilmede oldukça önemli avantajlar sağlamaktadır (Arslan, 2013-a; 2012-b).

Antalya milletvekillerinin yabancı dil bilgisi faktörü temelinde incelendiğinde de önemli bulgular ile karşılaşılır (Tablo 8). Antalya milletvekillerinin dörtte üçü en az bir yabancı dil bilmektedir. Birden fazla yabancı dil bilenlerin oranı da yüzde 25 'i aşmaktadır.

\subsection{ALDIKLARI EĞITTIMIN TÜRÜ VE MEZUN OLDUKLARI ÜNIVERSITTELER BAKIMINDAN ANTALYA MILLETVEKILLERİ}

Alınan eğitimin türü ve nereden alındığı da, en az alınan eğitimin miktarı kadar önemlidir. Görülen eğitimin türü ve alındığ 1 eğitim kurumu da elit ve özellikle de siyasal elit dolaşım süreci üzerinde önemli derecede etkilidir. $\mathrm{Bu}$ saptamadan yola çıkılarak, Antalya milletvekillerinin almış oldukları eğitimin türü ve bu eğitimi nerede aldıkları konusu da araştırma kapsamında incelendi. 


\section{Tablo-9}

Aldıkları Eğitim Türü Bakımından Antalya Milletvekilleri

\begin{tabular}{|c|c|c|c|c|}
\hline & & Sayı & $\%$ & $\begin{array}{c}\text { Birikimli } \\
\%\end{array}$ \\
\hline \multirow{11}{*}{ 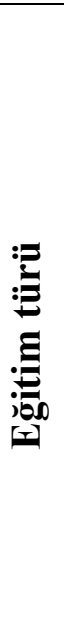 } & Hukuk & 31 & 20,4 & 20,4 \\
\hline & Mühendis-mimar & 20 & 13,2 & 33,6 \\
\hline & Sosyal-politik-ekonomik-ticari bilimler & 32 & 21,1 & 54,6 \\
\hline & Tip & 18 & 11,8 & 66,4 \\
\hline & Askeri & 4 & 2,6 & 69,1 \\
\hline & Eğitim & 13 & 8,6 & 77,6 \\
\hline & Orman-ziraat & 11 & 7,2 & 84,9 \\
\hline & İlahiyat & 2 & 1,3 & 86,2 \\
\hline & Tıbbi bilimler (diş-ziraat-veteriner) & 1 & ,7 & 86,8 \\
\hline & Öteki & 3 & 2,0 & 88,8 \\
\hline & İlişkisiz (üniversite eğitimi yok) & 17 & 11,2 & 100,0 \\
\hline \multicolumn{2}{|c|}{ Toplam } & 153 & & \\
\hline
\end{tabular}

Kaynak: Arslan’ın 2014 yılında gerçekleştirdiği araştırmanın verileri temel alınarak hazırlanmıştır.

Tablo ve Grafik 5'te de görüldügü gibi görülen eğitimin türü bağlamında, Antalya milletvekilleri arasında ilk sırayı, yüzde 21,1'lik oranla, sosyal, politik, ekonomik ve ticari alanlarda eğitim görmüş bireyler oluşturmaktadır. Hukuk alanında eğitim görmüş milletvekilleri ise yaklaşık yüzde 20'lik oranla ikinci sırada yer almaktadır. En küçük grubu ise tıbbi bilimler alanında eğitim görmüş milletvekilleri oluşturmaktadır. Bunları ilahiyat ve askeri eğitim görmüş milletvekilleri izlemektedir.

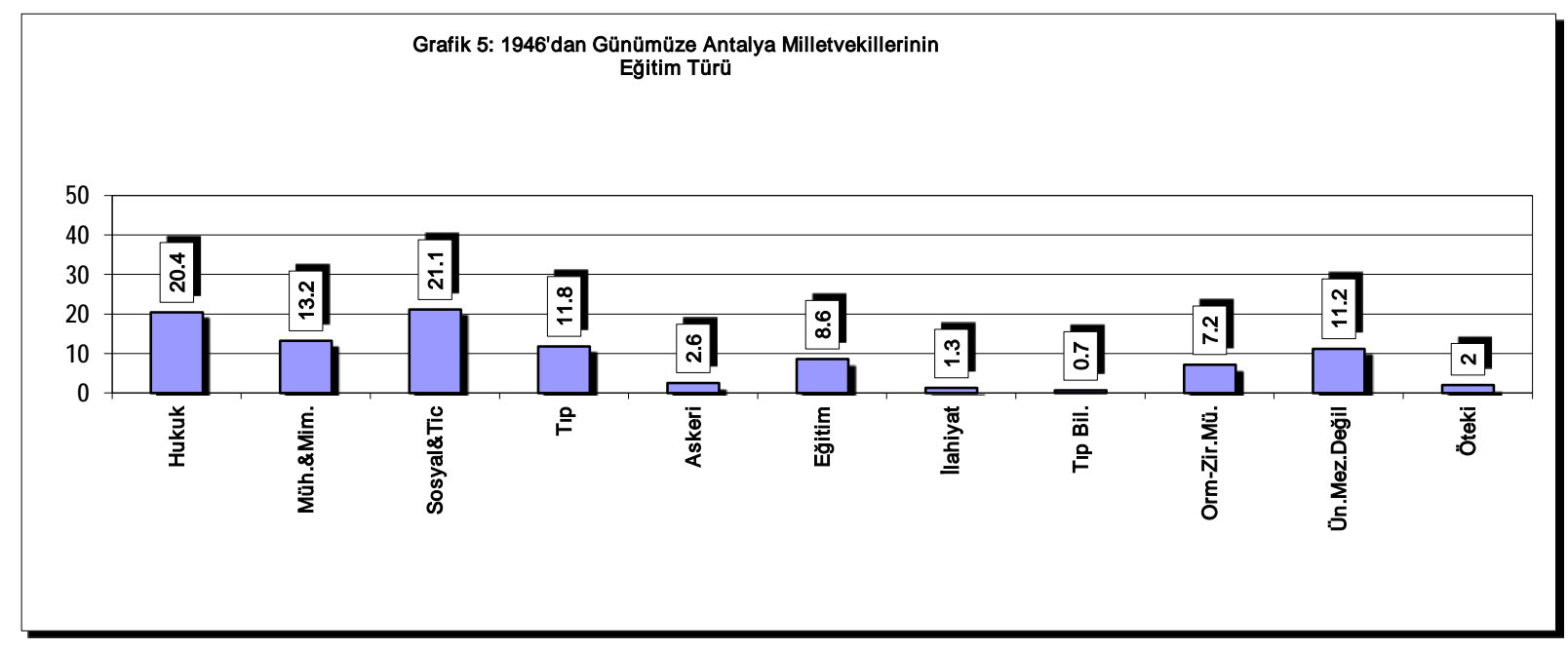


Daha önce de vurgulandığı gibi, gibi eğitimin alındığı kurum da elitlerin deveranında oldukça önemlidir. Dünyada olduğu gibi Türkiye'de de toplumsal yaşama yön veren elitlerin önemli bir bölümü, çoğunluğu metropol kentlerde yer alan ve köklü bir eğitim geleneğine sahip, "elit üniversiteleri”" olarak nitelendirilen üniversitelerden mezun olmuşlardır (Arslan, 2005).

Tablo-10

Antalya Milletvekillerinin Mezun Oldukları Üniversiteler

\begin{tabular}{|c|c|c|c|c|c|}
\hline & & Sayı & $\%$ & Geçerli \% & Birikimli \% \\
\hline & Öteki & 14 & 9,2 & 10,3 & 10,3 \\
\hline Üniversite & Adana & 1 & ,7 & ,7 & 11,0 \\
\hline & Akdeniz & 1 & ,7 & ,7 & 11,8 \\
\hline & Anadolu & 1 & ,7 & ,7 & 12,5 \\
\hline & Ankara & 43 & 28,1 & 31,6 & 44,1 \\
\hline & Berlin & 1 & ,7 & ,7 & 44,9 \\
\hline & Cenevre & 1 & ,7 & ,7 & 45,6 \\
\hline & Columbia & 1 & ,7 & ,7 & 46,3 \\
\hline & Edirne & 5 & 3,3 & 3,7 & 50,0 \\
\hline & Ege & 4 & 2,6 & 2,9 & 52,9 \\
\hline & Gazi & 2 & 1,3 & 1,5 & 54,4 \\
\hline & İstanbul & 54 & 35,3 & 39,7 & 94,1 \\
\hline & İzmir & 1 & ,7 & ,7 & 94,9 \\
\hline & Karadeniz & 1 & ,7 & ,7 & 95,6 \\
\hline & Köln & 1 & ,7 & ,7 & 96,3 \\
\hline & Selçuk & 3 & 2,0 & 2,2 & 98,5 \\
\hline & Viyana & 2 & 1,3 & 1,5 & 100,0 \\
\hline & Toplam & 136 & 88,9 & 100,0 & \\
\hline Ünivers & ezun değil & 17 & 11,1 & & \\
\hline Toplam & & 153 & 100,0 & & \\
\hline
\end{tabular}

Kaynak: Arslan'ın 2014 yılında gerçekleştirdiği araştırmanın verileri temel alınarak hazırlanmıştır.

$\mathrm{Bu}$ saptamalar 1şı̆̆ında, üniversite mezunu Antalya milletvekillerinin diplomalarını nereden aldıkları da araştırılmıştır. Grafik 6'da ve Tablo 10'da da görüldüğü gibi, Antalya milletvekillerinin büyük bir çoğunluğu Ankara ve İstanbul'daki köklü üniversitelerden mezun olmuşlardır. Ayrıca 6 milletvekili yurt dışında üniversite eğitimi görmüştür. Bunların beşi batı Avrupa üniversitelerinde, biri ise Amerika'da üniversite eğitimi görmüştür. 


\subsection{ANTALYA MILLETVEKILLERININ CINSIYYETI, MEDENI DURUMU VE ÇOCUK SAYISI}

Yukarıda ele alınan faktörler ilaveten, elit dolaşım sürecinde etkili olduğu bilinen, öteki bazı toplumsal ve demografik faktörler de vardır. Sıklıkla belirtildiği gibi bunların başında cinsiyet, medeni durum ve çocuk sayısı gibi faktörler sıralanabilir (Arslan, 2013-a; 2013-b). Bu saptamalar 1şığında araştırmada 1946'dan günümüze geçen 68 yıllık süreç içinde, Türkiye Büyük Millet Meclisi çatısı altında Antalya'yı temsil etmiş milletvekileri de cinsiyet, medeni durum ve çocuk sayısı gibi temel sosyolojik faktörler 1şı̆̆ında incelendi.

Başta klasik sosyoloji geleneğinin öncü isimlerinden Durkheim ve öteki birçok sosyal bilimcinin de vurguladığı gibi iş bölümü ve uzmanlaşma, toplum hayatının vazgeçilmez dinamiklerindendir. Toplumsal hayattaki iş bölümü üzerinde etkili olan değişkenlerden başta geleni cinsiyet faktörüdür.

Tablo-11

Antalya Milletvekillerinin ve Türk Siyasi Elitlerinin Cinsiyet Dağılımı

\begin{tabular}{|l|c|c|c|}
\hline \multirow{2}{*}{} & \multicolumn{2}{|c|}{ Cinsiyet (\%) } & \multirow{2}{*}{ Toplam } \\
\cline { 2 - 3 } & Kadın & Erkek & \\
\hline Antalya Milletvekilleri (1950-2006) & 1,3 & 98,7 & 100 \\
\hline Türk Siyasi Elitleri (1946-2006) & $\mathbf{1 . 7 7}$ & $\mathbf{9 8 . 2 3}$ & 100 \\
\hline
\end{tabular}

Kaynak: Arslan'ın 2014 yılında gerçekleştirdiği araştırmanın verileri temel alınarak hazırlanmıştır.

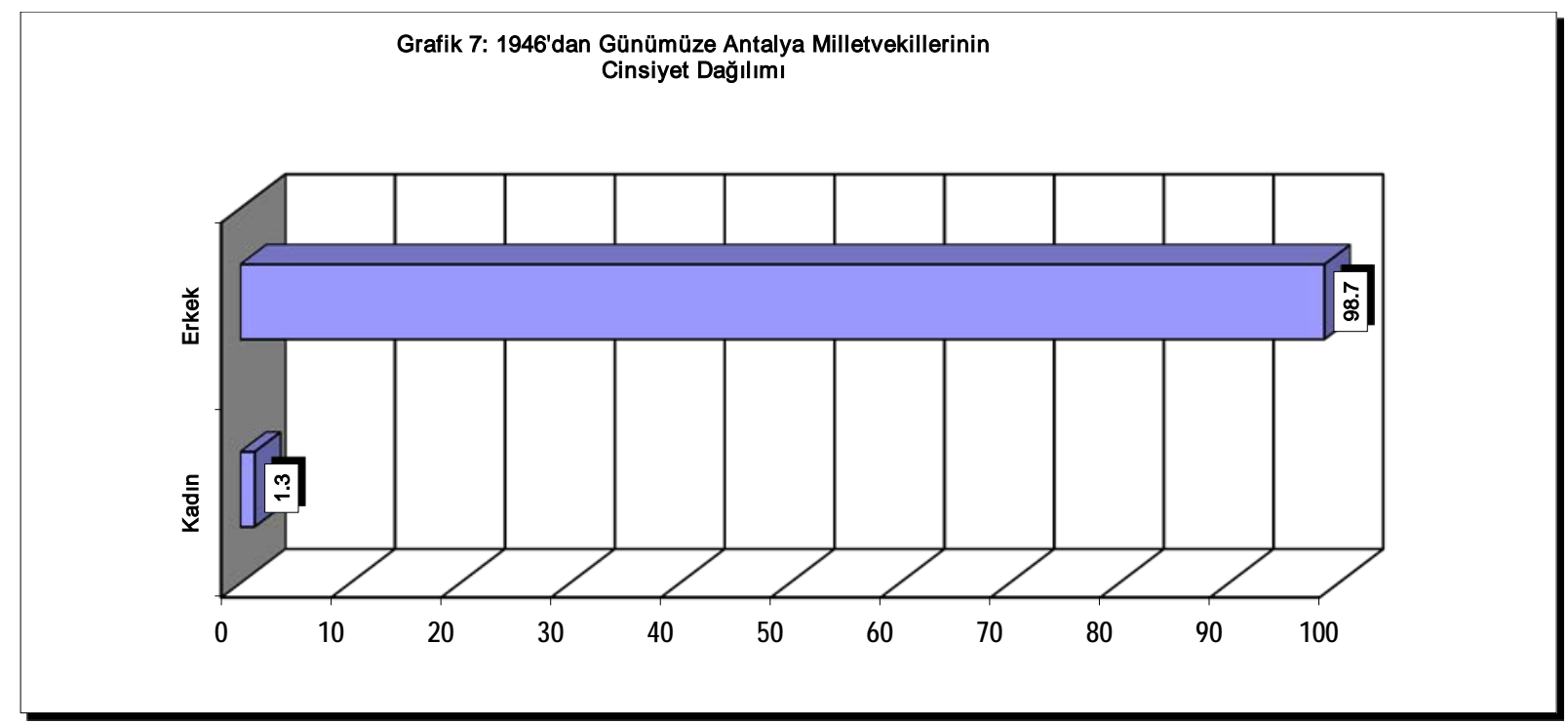

Antalya milletvekillerinin toplumsal profilleri, bu değişken temelinde incelendiğinde de oldukça anlamlı bulgulara ulaşılır. Tablo 11 ve Grafik 7'de de görüldüğü gibi, Antalya'nın 
toplumsal hayatında siyasal iktidarın şekillenmesinde, erkeklerin ezici bir ağırlığı göze çarpar. Bu saptama Türkiye geneli açısından da geçerlidir. Antalya milletvekilleri arasında kadının temsil edilme durumu, Türkiye geneli ortalamasına paralel bir görünüm sergiler. Hem Türkiye genelinde ve hem de Antalya milletvekilleri arasında kadın milletvekillerinin oranı yüzde 1'in biraz üzerindedir.

Bu başlık altında incelenen bir başka konu da milletvekillerinin medeni durumları ve sahip oldukları çocuk sayısıdır. Bilindiği üzere, dün olduğu gibi bugün de aile, toplumsal yap1 içinde hayati bir öneme sahiptir. Özellikle sosyal, ekonomik ve siyasal kriz dönemlerinde, "bir tampon kurum" olarak aile kurumunun üstlendiği rollerin önemi bir kat daha artar. Aile kurumun temelinde ise evlilik olgusu yatar. Evlilik üzerine inşa edilmeyen aileler için yapısal bir bütünlükten söz etmek mümkün değildir.

Tablo-12

Antalya Milletvekillerinin ve Türk Siyasi Elitlerinin Medeni Durumları

\begin{tabular}{|l|c|c|c|}
\hline \multirow{2}{*}{} & \multicolumn{2}{|c|}{ Medeni Durumu (\%) } & \multirow{2}{*}{ Toplam } \\
\cline { 2 - 3 } & Evli & Bekâr-Dul & \\
\hline Antalya Milletvekilleri (1950-2007) & 92,2 & 7,8 & 100 \\
\hline Türk Siyasi Elitleri (1946-2007) & $\mathbf{9 3 . 7}$ & $\mathbf{6 . 3}$ & 100 \\
\hline
\end{tabular}

Kaynak: Arslan'ın 2014 yılında gerçekleştirdiği araştırmanın verileri temel alınarak hazırlanmıştır.

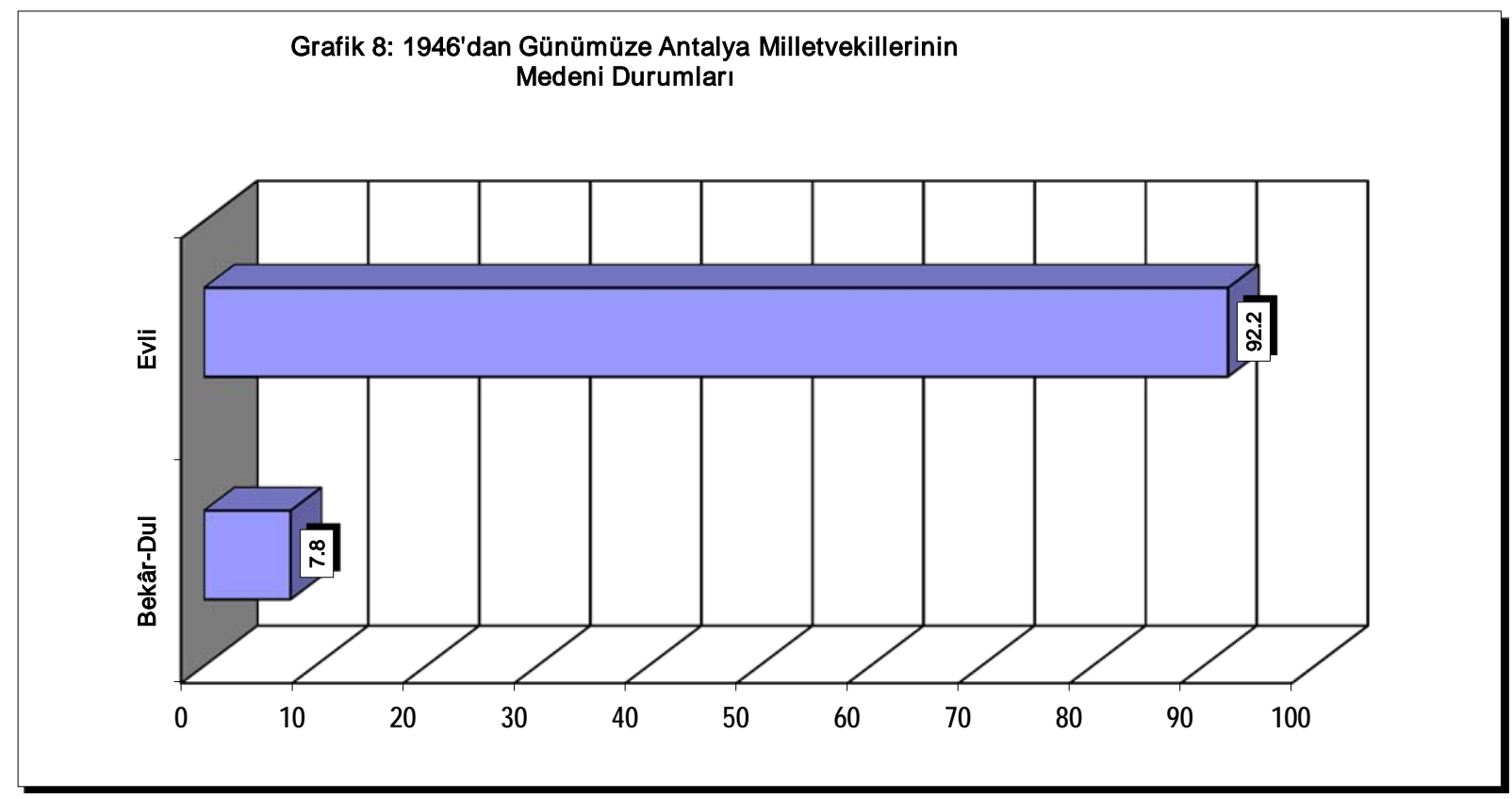

Bu saptamalardan yola çıkılarak araştırmada, Antalya milletvekillerinin, medeni durumları da incelendi. Tablo 12'de de görüldüğ̈̈ gibi genelde Türk siyasi elitleri arasında, özelde ise Antalya milletvekilleri içinde, evli milletvekilleri ezici bir çoğunluk oluştururlar. Medeni 
duruma ilişkin Türkiye geneli ve Antalya özeline ilişkin bulguların son derece benzer olması son derece anlamlıdır. Grafik 8'de de görüldüğü gibi, bekâr ya da dul milletvekillerinin Antalya milletvekilleri arasındaki varlığı yüzde 8'den daha azdır.

Tablo-13

Sahip Oldukları Çocuk Sayısı Bakımından Antalya Milletvekilleri ve Türk Siyasi Elitleri

\begin{tabular}{|l|c|}
\hline & Ortalama Çocuk Sayısı \\
\hline Antalya Milletvekilleri (1950-2007) & 2.18 \\
\hline Türk Siyasi Elitleri (1946-2007) & 2.5 \\
\hline \hline
\end{tabular}

Kaynak: Arslan'ın 2014 yılında gerçekleştirdiği araştırmanın verileri temel alınarak hazırlanmıştır.

Öte yandan çocuk sayısı bireylerin aile yapısı hakkında oldukça anlamlı ipuçları verir. Bu değişken temelinde, siyasi elitler incelendiğinde, hem Türkiye geneline ilişkin ve hem de Antalya'ya özel oldukça önemli sonuçlar ile karşılaş1lır. Tablo 13'te de görüldüğü gibi, Antalya milletvekillerinin ortalama çocuk sayısı 2,13'dir. Türkiye genelinde milletvekillerinin ortalama çocuk sayısı 2,5'tir. Açıkça görüldügü gibi, Antalya milletvekillerinin çocuk sayısı ise Türkiye ortalamasının bir hayli altındadır.

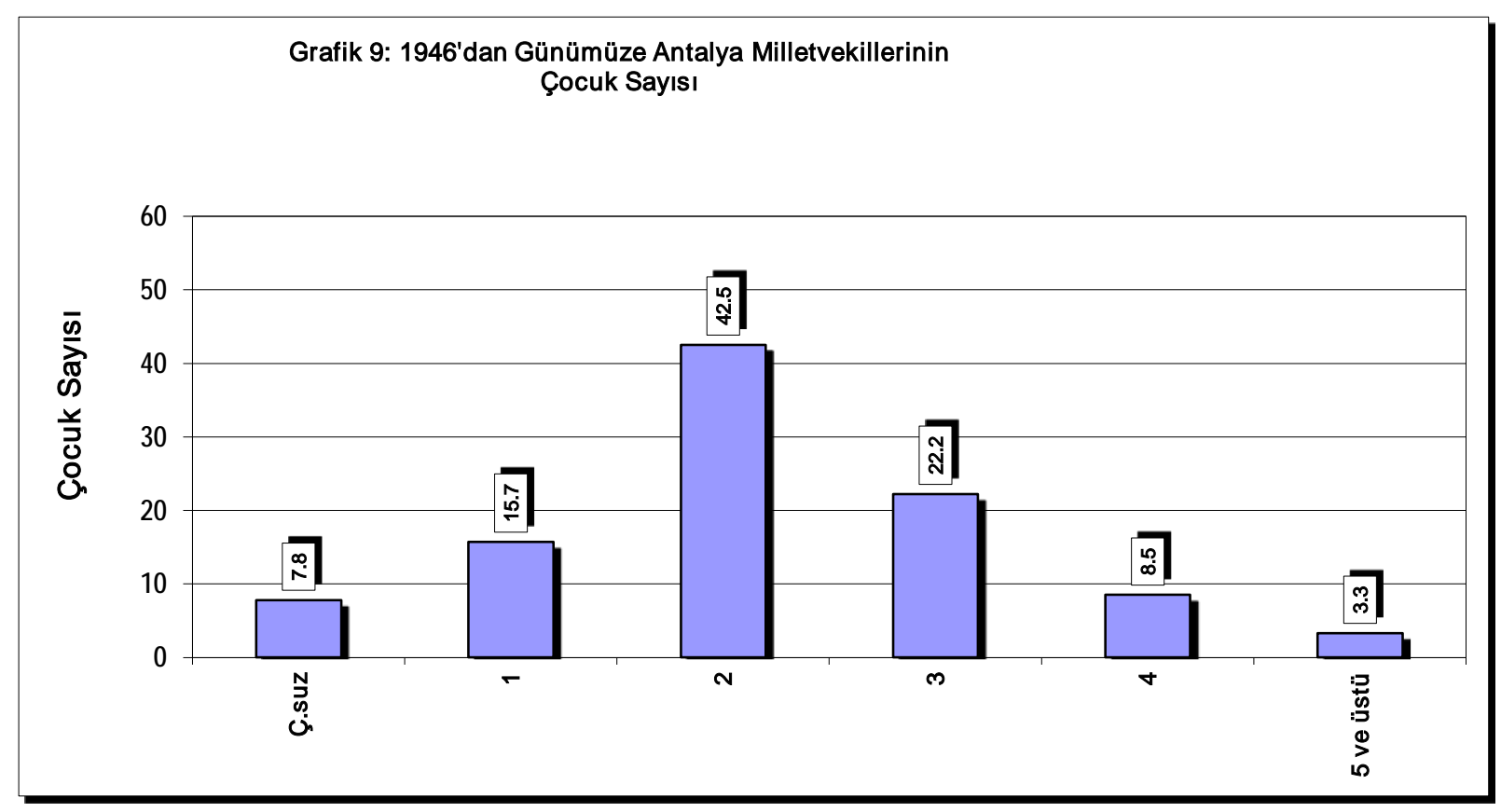


Tablo-14

Antalya Milletvekillerinin Çocuk Sayısı

\begin{tabular}{|l|l|c|c|c|c|}
\hline \multicolumn{2}{|c|}{} & Sayı & \% & Geçerli \% & Birikimli \% \\
\hline \multirow{4}{*}{ Çocuk sayısı } & Çocuksuz & 12 & 7,8 & 7,8 & 7,8 \\
\cline { 2 - 6 } & Bir & 24 & 15,7 & 15,7 & 23,5 \\
\cline { 2 - 6 } & İki & 65 & 42,5 & 42,5 & 66,0 \\
\cline { 2 - 6 } & Üç & 34 & 22,2 & 22,2 & 88,2 \\
\cline { 2 - 6 } & Dört & 13 & 8,5 & 8,5 & 96,7 \\
\cline { 2 - 6 } & Beş ve yukarıs1 & 5 & 3,3 & 3,3 & 100,0 \\
\cline { 2 - 6 } & Toplam & 153 & 100,0 & 100,0 & \\
\hline
\end{tabular}

Kaynak: Arslan'ın 2014 yılında gerçekleştirdiği araştırmanın verileri temel alınarak hazırlanmıştır.

Grafik 9 ve Tablo 14'teki bulgular, Antalya milletvekillerinin aile yapısı hakkında detaylı bilgiler sunar: Antalya milletvekillerinin yaklaşık yüzde 60'1 iki ya da daha az çocuk sahibidir. Üç ya da daha az çocuk sahibi olanların oranı ise yüzde $88^{\prime}$ i aşar. Dört ya da daha fazla çocuk sahibi olanların oranı yalnızca yüzde 11 civarındadır.

\subsection{ANTALYA MILLETVEKÍLLERİ ARASINDA ELITT DOLAŞIM HIZI}

Elit dolaşım hızını ölçmek amacıyla genellikle, siyasi elitlerin milletvekili seçilme sayılarına bakılır. Siyasi elitlerin milletvekili seçilme sayısı, elit dolaşım sürecine dair önemli ipuçları verir. Hatta elit dolaşım hızının yüksekliği, bazı araştırmacılar tarafından toplumsal ve siyasal hayatta fırsat eşitliğinin varlığı açısından da önemli bir indikatör olarak kabul ederler. Bunun da ötesinde, demokratikleşme süreci ile elit dolaşım hızı arasında ilişki de kurulur. Siyasi hayatta elit dolaşım hızı deniliğinde, parlamentonun yenilenme oranı akla gelir (Arslan, 2012b).

\section{Tablo-15}

Antalya Milletvekillerinin Milletvekili Seçilme Sayısı

\begin{tabular}{|l|l|c|c|c|c|}
\hline \multicolumn{2}{|c|}{} & Sayı & \% & Geçerli \% & Birikimli \% \\
\hline \multirow{3}{*}{ Seçilme sayısı } & 1 & 94 & 61,4 & 61,4 & 61,4 \\
\cline { 2 - 6 } & 2 & 29 & 19,0 & 19,0 & 80,4 \\
\cline { 2 - 6 } & 3 & 15 & 9,8 & 9,8 & 90,2 \\
\cline { 2 - 6 } & 4 & 7 & 4,6 & 4,6 & 94,8 \\
\cline { 2 - 6 } & 5 & 4 & 2,6 & 2,6 & 97,4 \\
\cline { 2 - 6 } & 6 & 2 & 1,3 & 0,7 & $9,7,3$ \\
\cline { 2 - 6 } & 7 & 153 & 100,0 & 100,0 & 99,3 \\
\cline { 2 - 6 } & 8 & & 1 & 0,7 & 100,0 \\
\cline { 2 - 6 } & Toplam & & & 1,7 & \\
\hline
\end{tabular}

Kaynak: Arslan'ın 2014 yılında gerçekleştirdiği araştırmanın verileri temel alınarak hazırlanmıştır. 
$\mathrm{Bu}$ vurgulamalar dikkate alınarak araştırmada, Antalya milletvekillerinin milletvekili seçilme sıklığ 1 da incelenmiştir. Tablo 20'de de görüldüğü gibi Antalya milletvekilleri arasında elit dolaşım hızı bir hayli yüksek düzeydedir. 1946'dan bugüne incelenen 17 dönemin genelinde Antalya milletvekillerinin yüzde 61 'den fazlası bir kere milletvekili seçilmiştir. Bir başka anlatımla Antalya milletvekillerinin ortalama yüzde 60'1, her dönem yenilenmektedir. Antalya milletvekilleri arasında iki ya da daha az dönem parlamenterlik yapmış milletvekillerinin toplam oranı yüzde 80 civarındadır. Bununla birlikte, üç ya da daha fazla dönem milletvekilliği yapmış parlamenterlerin oranı ise yüzde 20'ye ulaşmaktadır. Bu bulgular birlikte değerlendirildiğinde, Antalya'da, siyasal dikey hareketlilik kanallarının, göreceli de olsa, açık ve işler durumda olduğu söylenebilir.

\subsection{ANTALYA MILLETVEKİLERININ SEÇİLDİĞİ DÖNEM VE PARTİLER}

Toplumsal yapı içinde bireylerin siyasal davranışları (Aksoy, 200: 31-32) ve bu davranışların doğurduğu sonuçlar, siyaset sosyolojisi çalışmaları açısından çok büyük önem arz eder. Bireyler seçimlerdeki siyasal davranışlar ile bireyler toplumsal yapı içinde siyasal iktidarı şekillendirirler. Seçimlerdeki siyasal tercihleri ile bireyler, ülkenin yönetimine belirli bir dönem süresince yön verecek, toplumun değişim rotasını belirleyecek, toplumdaki bireylerin uyacakları kuralları ve oynayacakları rolleri belirleyecek (Arslan, 2003) güce ve konuma sahip siyasi elitlerin (Arslan, 2005-a; Arslan, 2005-b; Arslan, 2005-c; Arslan, 2004; Frey, 1965) kimler olacağını, bunun da ötesinde ülkenin bugünü ve yarınlarını şekillendirecek siyasal sistemi (Kışlalı, 2003: 238-268) de belirlemiş olmaktadırlar.

Demokratik sistemin bir gereği olarak her il, siyasal iktidarın merkezi kurumu olan Türkiye Büyük Millet Meclisi'ne, sahip olduğu nüfus ve öteki bazı kriterlerle orantılı olarak, belirli sayılarda siyasal temsilci gönderir. Kendilerini kimlerin temsil edeceğine, o kentin ve ilin sınırları içinde yaşayan seçmenler karar verir. İncelenen 68 yıllık süreçte yapılmış olan 17 genel seçimde parlamentoya Antalya, toplam 153 milletvekili göndermiştir. Antalyalılar parlamentoya en çok temsilciyi, On beş milletvekili ile 24. dönemde göndermişlerdir. İncelenen dönemler bazında Antalya, her yasama döneminde en az 7 milletvekili ile temsil edilmiştir Tablo 16). 
Tablo-16

Antalya Milletvekillerinin Milletvekili Seçildiği Dönem

\begin{tabular}{|l|l|c|c|c|c|}
\hline \multicolumn{2}{|l|}{} & Sayı & \% & Geçerli \% & Birikimli \% \\
\hline \multicolumn{1}{|l|}{ 8. Dönem (1946) } & 7 & 4,6 & 4,6 & 4,6 \\
\cline { 2 - 6 } & 9. Dönem (1950) & 7 & 4,6 & 4,6 & 9,2 \\
\hline 10. Dönem (1954) & 8 & 5,2 & 5,2 & 14,4 \\
\hline 11. Dönem (1957) & 9 & 5,9 & 5,9 & 20,3 \\
\hline 12. Dönem (1961) & 7 & 4,6 & 4,6 & 24,8 \\
\hline 13. Dönem (1965) & 7 & 4,6 & 4,6 & 29,4 \\
\hline 14. Dönem (1969) & 7 & 4,6 & 4,6 & 34,0 \\
\hline 15. Dönem (1973) & 7 & 4,6 & 4,6 & 38,6 \\
\hline 16. Dönem (1977) & 7 & 4,6 & 4,6 & 43,1 \\
\hline 17. Dönem (1983) & 7 & 4,6 & 4,6 & 47,7 \\
\hline 18. Dönem (1987) & 8 & 5,2 & 5,2 & 52,9 \\
\hline 19. Dönem (1991) & 9 & 5,9 & 5,9 & 58,8 \\
\hline 20. Dönem (1995) & 10 & 6,5 & 6,5 & 65,4 \\
\hline 21. Dönem (1999) & 12 & 7,8 & 7,8 & 73,2 \\
\hline 22. Dönem (2002) & 13 & 8,5 & 8,5 & 81,7 \\
\hline 23. Dönem (2007) & 13 & 8,5 & 8,5 & 90,2 \\
\hline 24. Dönem (2011) & 15 & 9,8 & 9,8 & 100,0 \\
\hline
\end{tabular}

Tablo-17

Antalya Milletvekillerinin Milletvekili Seçildiği Parti

\begin{tabular}{|l|l|c|c|c|c|}
\hline \multicolumn{2}{|c|}{} & Sayı & \% & Geçerli \% & Birikimli \% \\
\hline \multirow{4}{*}{ Partiler } & Ak Parti & 17 & 11,1 & 11,1 & 11,1 \\
\cline { 2 - 6 } & ANAP & 11 & 7,2 & 7,2 & 18,3 \\
\cline { 2 - 6 } & AP & 22 & 14,4 & 14,4 & 32,7 \\
\cline { 2 - 6 } & CHP & 39 & 25,5 & 25,5 & 58,2 \\
\cline { 2 - 6 } & DP & 25 & 16,3 & 16,3 & 74,5 \\
\cline { 2 - 6 } & DSP & 4 & 2,6 & 2,6 & 77,1 \\
\cline { 2 - 6 } & DYP & 17 & 11,1 & 11,1 & 88,2 \\
\cline { 2 - 6 } & FP & 1 & 0,7 & 0,7 & 88,9 \\
\cline { 2 - 6 } & HP & 1 & 0,7 & 0,7 & 89,5 \\
\cline { 2 - 6 } & MDP & 2 & 1,3 & 1,3 & 90,8 \\
\cline { 2 - 6 } & MHP & 10 & 6,5 & 6,5 & 98,4 \\
\cline { 2 - 6 } & RP & 1 & 0,7 & 0,7 & 100,0 \\
\cline { 2 - 6 } & SHP & 3 & 2,0 & 2,0 & \\
\cline { 2 - 6 } & Toplam & 153 & 100,0 & 100,0 & \\
\hline
\end{tabular}


Partilerin seçildikleri siyasi partiler, o kentin siyasal iktidarın dokusun hususunda son dererce önemli ipuçları verir. Antalya milletvekillerinin seçildiği siyasi partiler incelendiğinde ise Antalya'nın siyasi yapısına ilişkin bazı önemli ipuçlarına ulaşılır. Genel olarak incelendiğinde, Türkiye'nin siyasi ve toplumsal hayatında ağırlıklı olarak sağ siyaset anlayışının egemen olduğu gerçeği ile karşılaşılır. Siyasal hayatta, sol yelpazedeki partilerin de iktidarı elinde bulundurduğu bazı dönemler gözlemlenmiş olsa da, sol siyaset geleneği ülke siyasi hayatında kalıcı olamamıştır (Arslan, 2006). Siyasi partilerin iktidar yapısı içindeki temsil gücü bakımından Antalya'nın durumu da, Türkiye geneline paralel bir görünüm sergiler. Daha net bir anlatımla, bazı dönemler daha belirgin bazı dönemler de daha zayıf olsa da, Antalya'nın siyasi yapısında merkez sağ yelpazeden siyasi partiler ön plana çıkmıştır (Tablo 22).

\section{GENEL DEĞERLENDİRME VE SONUÇ}

Başlangıçta da vurgulandığı gibi bu çalışmada, Antalya milletvekillerinin sosyolojik açıdan incelenmiştir. Böylece, Antalya'da elit dolaşım sürecinin ve siyasal iktidarın sosyolojik dinamiklerinin ortaya konması hedeflendi. Araştırmanın kapsamına, çok partili siyasal yaşam yani 1946-2014 süreci dâhil edildi. Daha önce de değinildiği gibi 1946 y1lı genel seçimleri, "şaibeli seçimler" olarak kabul edilse de, gerçek çok partili hayata tam geçişin gerçekleştirildiği 1950 genel seçimlerinin hazırlayıcısı olması bakımından son derece büyük önem arz eder.

Ülkemizde çok partili dönemde, yani 1946’dan günümüze toplam 17 genel seçim gerçekleştirilmiştir. Çalışmada, bu genel seçimlerin sonuçları Antalya ili özelinde incelendi. Antalya'ya ilişkin bulgular zaman zaman, Türkiye geneline yönelik bulgularla karşılaştırıldı. Böylece, iktidar yapısı bakımından Antalya'nın Türkiye'nin siyasi yapısı içindeki yeri anlaşılmaya çalışıldı.

Araştırmada siyaset sosyolojisi ve özellikle de elit sosyolojisinin teorik ve metodolojik birikimlerinden yararlanıldı. Kuramsal açıdan, elit teorisinin bir alt dalı olan elitist (seçkinci) elit teorisi kullanıldı. Araştırmanın bulguları doğrultusunda, araştırmanın başlangıcında belirlenen soruların cevapları şöylece özetlenebilir: Antalya milletvekillerinin ortalama yaşı 48.55'tir. Bu sayı, Antalya milletvekilleri arasında genç, özellikle de orta-genç yaş grubunun belirleyici bir ağırlığının varlığına işaret eder. Yaş ile ilgili mod ve medyan da bu bulguyu destekler doğrultudadır. Bu bulgular temelinde, yaş ile değişkeni ile şu saptamalar yapılabilir.

- $\quad$ Antalya'nın siyasi yapısı içinde milletvekili seçilebilmek için yaş faktörü belirleyici bir etkiye sahiptir.

- Genç (Orta-genç) yaş grubu milletvekili adaylarının, Antalya'dan milletvekili seçilme olasılığı, ileri yaş grubu bireylere oranla daha yüksektir.

Araştırmadaki meslek ile ilgili sorulara da, ulaşılan bulgular 1şığında, şu cevaplar verilebilir: Antalya'nın siyasi ve toplumsal hayatında, eğitimci bilim insanlarının belirleyici bir ağırlığı 
vardır. Bunları hukukçular (avukat, hâkim ve savcılar), doktorlar, mühendisler ile sivil bürokrat ve yöneticiler izler. Özetle:

- Bazı meslek grupları, Antalya'da siyasi elit dolaşım sürecinde daha belirleyici etkiye sahiptir.

- $\quad$ Milletvekili adaylarının üniversite hocası olması, öteki meslek gruplarından daha fazla etkilidir.

- Meslek olarak hukukçu milletvekili adaylarının Antalya'dan milletvekili seçilebilme olasılığı öteki meslek gruplarına oranla daha yüksektir.

- $\quad$ Milletvekili adaylarının üst düzey bürokrat-yönetici olması, Antalya'da milletvekili seçilmesinde pozitif yönde bir etki yapar.

- $\quad$ Meslek olarak tüccar ve sanayicilik, Antalya’dan milletvekili seçilebilmek için pozitif yönde bir etki yapsa da, tüccar ve sanayicilerin Antalya'nın siyasi yapısı içindeki yeri, Türkiye genelinden daha geri plandadır. Buna karşın, Türkiye genelinden farklı olarak doktorlar Antalya'nın toplumsal yapısında daha etkin rol oynar.

Cinsiyet faktörü de, Antalya'nın siyasi yapısı içinde iktidarın şekillenmesinde ve elit dolaşım süreci üzerinde, son derece etkili bir rol oynamaktadır. Erkek milletvekillerinin, Antalya milletvekilleri arasında, yüzde 98,7 gibi ezici bir üstünlüğü olduğu dikkate alındığında, aşağıdaki bulgular kolayca söylenebilir.

- $\quad$ Milletvekili adaylarının cinsiyeti, Antalya'da milletvekili seçimi sürecinde belirleyici bir etkiye sahiptir.

- $\quad$ Milletvekili adaylarının erkek olması, Antalya'da milletvekili seçimi sürecinde pozitif yönde bir etki yapar. Antalya'nın toplumsal ve siyasal yaşamında gözlemlenen maskülin karakter, Türkiye geneline paralellik gösterir.

Bulgular, eğitim faktörünün de Antalya'da siyasal iktidarın şekillenmesinde etkili rol oynadığını göstermektedir. Araştırma bulguları, Antalya milletvekillerinin yüzde 88'den fazlasının üniversite mezunu olduğunu göstermektedir. Bu bağlamda şu sonuçlara ulaşılır:

- $\quad$ Eğitim durumu Antalya'da milletvekili seçimi sürecinde belirleyici bir etkiye sahiptir.

- Aldığı eğitimin miktarı arttıkça, milletvekili adayının Antalya'dan milletvekili seçilebilme olasılı̆̆ da artar.

- $\quad$ Üniversite mezunu olmak, milletvekili adayının Antalya'dan milletvekili seçilmesinde pozitif yönde belirleyici rol oynar. Üniversite mezunu olmak Antalya’da, Türkiye genelinden çok daha fazla önem arz eder.

- Alınan eğitimin türü de milletvekili adayının Antalya'dan milletvekili seçilmesinde pozitif yönde etki yapar.

Antalya milletvekillerinin yabancı dil bilgileri ve mezun oldukları üniversiteler ile ilgili bulgular da şöylece özetlenebilir: Antalya milletvekillerinin yaklaşık beşte dördü, en az bir 
yabancı dil bilmektedir. Öte yandan üniversite mezunu milletvekillerinin büyük çoğunluğu metropol kentlerdeki üniversitelerden mezun olmuştur. Hal böyle olunca:

- Yabancı dil bilmek, Antalya'da milletvekili seçimi sürecinde pozitif yönde bir etki yapar.

- $\quad$ Metropol kentlerdeki köklü üniversitelerden alınan diplomalar, milletvekili adayının Antalya'dan milletvekili seçilmesinde pozitif yönde etki yapar.

Antalya milletvekilleri, medeni durum ve aile yapısı temelinde incelendiğinde, Antalya milletvekillerinin yüzde 92'den fazlasının evli olduğu gerçeği ile karşılaşılır. Milletvekillerinin sahip oldukları ortalama çocuk sayısı ise Türkiye ortalamasının oldukça altındadır. Özetle:

- Milletvekili adayının medeni durumu, Antalya'dan milletvekili seçilmesinde belirleyici yönde etki yapar.

- $\quad$ Evli olmak, bireylerin milletvekili seçilmesini olumlu yönde etkiler.

- Antalya'nın siyasi yapısının şekillenmesinde, çekirdek aile yapısına sahip milletvekilleri, geleneksel geniş aile yapısına sahip milletvekillerinden daha fazla etkiye sahiptir.

Özetle, sosyolojik profilleri bağlamında Antalya milletvekilleri eşitlikçi olmayan bir görünüm sergiler. Bazı toplum kesimleri, Antalya milletvekilleri arasında daha fazla temsil edilirken, öteki bazı kesimler toplumsal yapı içindeki oranlarına göre daha az temsil edilmekte, bazı kesimler ise hiç temsil edilme imkânı bulamamaktadır. Antalya milletvekilleri ile ilgili bulgular bir bütün olarak değerlendirildiğinde, Antalya'da iktidar yapısının seçkinci (elitist) elit teorisi ile paralellik gösterdiği gerçeği ile karşılaşılır. 


\section{REFERENCES}

- AARONOVITCH, S. (1961). The Ruling Class, London: Lawrence \& Wishart.

- AKSOY, M. (2000). Sosyoloji ve Sosyal Bilimlere Giriş, İstanbul: Alfa Yayınları.

- ALTUNIŞIK, R. ve Coşkun, R. (vd.) (2004). Sosyal Bilimlerde Araştırma Yöntemleri (SPSS Uygulamalı), Sakarya: Sakarya Kitabevi.

- ARSLAN, D.A. \& BAŞTÜRK, S. (vd.) (2014). Siyaset Sosyolojisi Perspektifinden 2009 ve 2014 Yerel Seçimlerinin Karşılaştırmalı İncelemesi. Akademik Bakış, İktisat ve Girişimcilik Üniversitesi, Türk Dünyası Kırgızistan-Celalabat İşletme Fakültesi, Uluslararası Sosyal Bilimler Dergisi, 43, 1-27.

- ARSLAN, D.A. (vd.) (2013-a). Çok Partili Dönemde Diyarbakır milletvekilleri: Geçmişten geleceğe Diyarbakır milletvekillerinin sosyolojik analizi. Sosyal Bilimler Araştırma Dergisi. 21, 47-84.

- ARSLAN, D.A. \& ARSLAN, G. (2013-b). Geçmişten günümüze Artvin milletvekilleri: 1946'dan bugüne Artvin milletvekillerinin sosyolojik analizi. Karadeniz Araştırmaları (Balkan, Kafkas, Doğu Avrupa ve Anadolu İncelemeleri) Dergisi. 36, 43-70.

- ARSLAN, A. (2012-a). Sosyoloji ve Yöntem Yazıları, Ankara: Kalkan Matbaacılık.

- ARSLAN, A. (2012-b). "Mersin Milletvekillerinin Sosyolojik Profilleri”, Uluslararas1 İnsan Bilimleri Dergisi, 9-1, 587-622. 17.01.2013, http://www.insanbilimleri.com/.

- ARSLAN, D. A. (2011-a). Turkish Political Elites: Sociological Analysis of Turkish Politics and Politicians. Berlin: LAP LAMBERT Academic Publishing.

- ARSLAN, D. A. (2011-b). Who Rules Turkey: Turkish Power Elite. Berlin: LAP LAMBERT, Academic Publishing.

- ARSLAN, D. A. (2011-c). Elites and Power in Contemporary Turkey: Social Anatomy of Turkish Elites. Berlin: LAP LAMBERT Academic Publishing.

- ARSLAN, A. (2007), Elit Sosyolojisi, Ankara: Phoenix Yayınları.

- ARSLAN, A. (2006), “12 Eylül 1980 Askeri Müdahalesi Sonrası Türkiye'nin Siyasi Yapısı", Akademik Bakış, İktisat ve Girişimcilik Üniversitesi, Türk Dünyası Kırgızistan-Celalabat İşletme Fakültesi, Uluslararası Sosyal Bilimler Dergisi, Sayı: 11, Y1l: 2006, ss.: 1-28.

- ARSLAN, A. (2005), "Educational Bases of Turkish Democracy: Educational Backgrounds of Turkish Elites", Sosyoloji Araştırmaları Dergisi (Journal of Sociological Research), Cilt: 8, Sayı: 1, Bahar 2005, ss. 5-30.

- ARSLAN, A. (2005-a), “Tek Partili Dönem ve Çok Partili Dönem Türk Siyasi Elitlerinin Toplumsal Profillerinin Karşılaştırmalı İncelemesi", "İş-Güç" Endüstri İlişkileri ve İnsan Kaynakları Dergisi, cilt: 7, Sayı: 1, 2005, http://www.isguc.org/arc_view.php?ex=240, 8.3.2005.

- ARSLAN, A. (2005-b), "The Evaluation Of Parliamentary Democracy In Turkey And Turkish Political Elites". Historia Actual On-Line, (Contemporary History Association - Asociacion De Historia Actual) v. 3, n. 6 (2005) (Revista Electrónica «Historia Actual On-Line», Año III, $\mathrm{N}^{\mathrm{O}}$ 6, Invierno 2005), http://www.hapress.com/abst.php?a=n06a10.

- ARSLAN, A. (2004-a), "The Theories on the Power: Elite Theory", "İş-Güç" Endüstri İlişkileri ve İnsan Kaynakları Dergisi, cilt: 6, Sayı: 1, 2004, http://www.isguc.org/arc_view.php?ex=193

- ARSLAN, A. (2004-b), "The Theories on the Power 2: Class Theory", "İş-Güç" Endüstri İlişkileri ve İnsan Kaynakları Dergisi, cilt: 6, Sayı: 2, 2004 , http://www.isguc.org/. 
- ARSLAN, A. (2004-c), "Türkiye'de İktidarın Sosyolojik Anatomisi ve Türk İktidar Seçkinleri”, Dokuz Eylül Üniversitesi Sosyal Bilimler Enstitüsü Dergisi, Cilt: 6, Sayı: 1, 1 Ocak-31 Mart 2004, ss. 1-25.

- ARSLAN, A. (2004-d), "Türk İktidar Seçkinleri”, Kırgızistan Kommersiyalık Enstitüsü, Akademik Bakış, Türk Dünyası Celalabad İşletme Fakültesi Sosyal Bilimler Dergisi, $\quad$ Sayı: 3, $2004, \quad$ ss.: $\quad$ 1-9, http://www.tdcif.org/a_view.php?pg=arc_view\&ex=13

- ARSLAN, A. (2004-e), “Turkish Political Elites (Türk Siyasi Elitleri)”, International Journal of Human Sciences, Political Science, 20.12.2004, http://www.insanbilimleri.com/en,

- ARSLAN, A. (2004-f), "Social Anatomy of Turkish Top Political Elites in Contemporary Turkey”, International Journal of Human Sciences, Political Science, 21.12.2004, http://www.insanbilimleri.com/en,

- ARSLAN, A. (2004-g), “Cumhuriyet'ten Günümüze Türk Siyasi Hayatında Eşitsizlikler”, Uluslararası İnsan Bilimleri Dergisi, Siyaset Bilimi 01.01.2005, http://www.insanbilimleri.com/.

- ARSLAN, A. (2004-h), "Çağdaş Türk Toplumunun Siyasi Hayatında Kadının Yeri ve Türk Siyasi Elitleri Arasında Kadının Temsil Edilme Durumu”, Kadın Çalışmalarında Disiplinlerarası Buluşma Sempozyumu Kitabı, Cilt: 3, Ss.: 101-110, İstanbul: Yeditepe Üniversitesi.

- ARSLAN, A. (2004-1), “Türk Medya Elitleri: Bir Durum Tespiti”, Sosyoloji Araştırmaları Dergisi (Journal of Sociological Research), Cilt: 4, Sayı: 2, Kış 2001, ss. 135-164.

- ARSLAN, A. (2004-j), “Türkiye'nin Siyasi ve Toplumsal Değişme Sürecinde Ordu ve Türk Askeri Elitleri”, Sosyoloji Araştırmaları Dergisi (Journal of Sociological Research), Cilt: 6, Sayı: 1, Bahar 2003, ss. 5-28.

- ARSLAN, A. (2003-a), "Eşitsizliğin Teorik Temelleri: Elit Teorisi, Kocaeli Üniversitesi, Sosyal Bilimler Enstitüsü Dergisi, Cilt: 6, Say1: 2003-2, ss. 115-135.

- ARSLAN, A. (2003-b), "Elit Teorisi Işı̆̆ında Günümüz Türk Toplumunun Genel Bir Değerlendirmesi”, Sosyoloji Araştırmaları Dergisi (Journal of Sociological Research), Cilt: 6, Say1: 2, Güz/Autumn 2003, ss. 5-30, Ankara,

- ARSLAN, A. (2003-c), “A Different Modernisation Experience In the Middle East: The Army And Modernisation In Turkey”, Fırat Üniversitesi Orta Doğu Araştırmaları Merkezi Orta Doğu Araştırmaları Dergisi, Cilt: 1, Sayı: 2, Temmuz 2003, ss.: 151168 ,

- ARSLAN, A. (2003-d), “Çok Partili Dönem Türk Siyasi Elitlerinin Sosyolojik Profilleri”, Jeopolitik Bilimsel Araştırmalar Dergisi, Cilt: 2, Say1: 7, Yaz 2003, ss. 131-138, İstanbul.

- ARSLAN, A. (2003-e), "Emergence Of The Turkish Bourgeoisie And BusinessPolıtıcs Relations In Turkey", "İş-Güç" Endüstri İlişkileri ve İnsan Kaynakları Dergisi, cilt: 5, Sayı: 2, 2003,

- ARSLAN, A., (2003-f) "Elit Teorisi Işı̆̆ında Günümüz Türk Toplumunun Genel Bir Değerlendirmesi”, Sosyoloji Araştırmaları Dergisi (Journal of Sociological Research), Cilt: 6, Sayı: 2, ss. 5-30, Güz / Autumn 2003.

- ARSLAN, A., (2001), “Cumhuriyet Dönemi (1920-1995)Türk Siyasi Elitlerinin Toplumsal Profili (Sociological Profiles of Turkish Political Elites in Republican Era)”, Osmangazi Üniversitesi Sosyal Bilimler Dergisi, Sayı: 2, 2001, ss. 5-16. 
- ARSLAN, A. (1998), “The Theories On Inequality: Elite Theory and Class Theory”, 18 March 1998, Guildford: University of Surrey, Department of Sociology.

- ARSLAN, A. (1995), Turkish Political Elites: Social Construction of Turkish Political Elites and Top Political Leadership in Turkey, Guildford: University of Surrey, Department of Sociology.

- BACHRACH, P. \& Baratz, M. (1962), "Two Faces of Power", American Political Science Review, vol. LVI.

- BULMER, M. (1994), Sociological Research Methods, London: Macmillan.

- ÇAĞLAR, A. \& ARSLAN, A. (2000), "Cumhuriyet'ten Günümüze Türk Siyasi Liderleri: Atatürk'ten Demirel'e Üst Siyasi Elitler”, Hacettepe Üniversitesi, İktisadi ve İdari Bilimler Fakültesi Dergisi, c. 8, s. 2/200, s. 499-514.

- DAHL, R. (1961), Who Governs?, New Haven, Yale UP.

- DOMHOFF, W. (1970), The Higher Circles, NewYork: Prentice Hall.

- DUVERGER, M. (1995), Siyasal Rejimler (The Political regimes), İstanbul: İletişim Y.

- DUVERGER, M. (1964), Political Parties: Their Organisation and Activity in the Modern State, London: Methuen \& Co. Ltd.

- ETZIONI, H. E. (1997), Class \& Elites in Democracy and Democratisation, NewYork: Garland Publishing.

- ETZIONI, H. E. (1993), The Elite Connection, London: Polity Press.

- FREY, W.F. (1965), The Turkish Political Elite, Massachusetts: MIT Press.

- GILBERT, N. (1997), Analysing Tabular Data, London: Sage.

- GILBERT, N. (1994), Researching Social Life, London: Sage.

- HEALEY, J. F. (1993), Statistics: A Tool For Social Research, Califonia: Wadsworth.

- HERTZ, R. \& Imber, J. B. (1995), Studying Elites Using Qualitative Methods, London: Sage.

- HunTER, F. (1953), Community Power Structure, Chapel Hill: University of Carolina Press.

- JARY, D. \& Jary, J. (1991), Dictionary of Sociology, Glasgow: Harper Collins.

- KIZILÇELİK, S. \& Erjem, Y. (1992) Açıklamalı Sosyoloji Terimler Sözlüğü, Konya: Emre.

- LANDAU, J. M., Özbudun, E., \& Tachau, F. (1980) Electoral Politics in the Middle East, London: Cronm Helm.

- MACDONALD, M. (1977), The Education of Elites, Milton Keynes: Open University Press.

- MEISEL, J. (1962), The Myth of the Rulling Class: Gaetano Mosca and Elite, Michigan: University Press.

- $\quad$ MILLS, C.W. (1956), The Power Elite, London: Oxford.

- MOSCA, G. (1939), The Ruling Class, New York: McGraw Hill.

- MOYSER, G. \& Wagstaffe, M. (1987), Research Methods for Elite Studies, London: Allen and Unwin.

- PARETO, V. (1968), The Rise and Fall of the Elites, New Jersey: The Bedminster.

- PRESTHUS, R. (1964), Men at the Top, New York: Oxford University Press.

- PUTNAM, R. (1976), The Comparative Study of Political Elites, New Jersey: Prentice Hall.

- SCOTT, J. (1993), Sociology of Elites, Aldershot: Elgar.

- SCOTT, J. (1991), Social Network Analysis: A Handbook, London: Sage. 
- $\quad$ SCOTT, J. (1991), Who Rules Britain, Cambridge: Polity Press.

- SCOTT, J. (1990), A Matter of Record: Documentary Sources in Social Research, Cambridge: Polity Press.

- SCOTT, J. (1986), " Does Britain Still have a Ruling Class?", Social Studies Review, vol. 2, pp. 2-7.

- TBMM (2003), TBMM Albümü 22. Dönem (TGNA-Turkish Grand National Assembly Album), Ankara: TBMM Basimevi.

- TBMM (2000), TBMM Albümü 21. Dönem (TGNA-Turkish Grand National Assembly Album), Ankara: TBMM Basımevi.

- TBMM (1997), TBMM Albümü 20. Dönem (TGNA-Turkish Grand National Assembly Album), Ankara: TBMM Basımevi.

- TBMM (1994), TBMM Albümü 1920-1991 (TGNA-Turkish Grand National Assembly Album), Ankara: TBMM Basımevi.

- TBMM (1992), TBMM Albümü 19. Dönem (TGNA-Turkish Grand National Assembly Album), Ankara: TBMM Basımevi.

- THOENES, P. (1966), Elites in the Welfare State Toronto: Trans Canada Press.

- TURHAN, M. (1991), Siyasal Elitler, Ankara: Gündoğan Yayınları.

- WEBER, M. (1968). Economy and Society: An Outline of interpretive Sociology, New York: Bedminster Press.

- YÜCEKÖK, A.N. (1983), Türkiye'de Parlamentonun Evrimi (The Evaluation of the Parliament in Turkey), Ankara: Ankara University. 